\title{
Biomass Derived Chemicals: Furfural Oxidative Esterification to Methyl-2-furoate over Gold Catalysts
}

\author{
Maela Manzoli ${ }^{1, *}$, Federica Menegazzo ${ }^{2}$, Michela Signoretto ${ }^{2}$ and Damiano Marchese ${ }^{2}$ \\ 1 Department of Chemistry, University of Turin, NIS Centre of Excellence, Via P. Giuria 7, 10125 Torino, Italy \\ 2 Department of Molecular Sciences and Nanosystems, Ca' Foscari University Venice and INSTM \\ Consortium RU Ve, Via Torino 155, 30170 Venezia Mestre, Italy; fmenegaz@unive.it (F.M.); \\ miky@unive.it (M.S.); falkiuzz@hotmail.it (D.M.) \\ * Correspondence: maela.manzoli@unito.it; Tel.: +39-011-670-7541
}

Academic Editors: Leonarda Liotta and Salvatore Scirè

Received: 16 March 2016; Accepted: 14 July 2016; Published: 20 July 2016

\begin{abstract}
The use of heterogeneous catalysis to upgrade biomass wastes coming from lignocellulose into higher value-added chemicals is one of the most explored subjects in the prospective vision of bio-refinery. In this frame, a lot of interest has been driven towards biomass-derived building block molecules, such as furfural. Gold supported catalysts have been successfully proven to be highly active and selective in the furfural oxidative esterification to methyl-2-furoate under mild conditions by employing oxygen as benign oxidant. Particular attention has been given to the studies in which the reaction occurs even without base as co-catalyst, which would lead to a more green and economically advantageous process. The Au catalysts are also stable and quite easily recovered and represent a feasible and promising route to efficiently convert furfural to methyl-2-furoate to be scaled up at industrial level.
\end{abstract}

Keywords: gold catalyst; $\mathrm{Au} / \mathrm{ZrO}_{2} ; \mathrm{Au} / \mathrm{CeO}_{2} ; \mathrm{Au} / \mathrm{TiO}_{2} ; \mathrm{Au}$ clusters; $\mathrm{Au}$ perimeter sites; furfural; esterification; biomass

\section{Furfural as Platform Molecule Coming from Biomass}

Climate change and the exhaustion of fossil fuel reserves have increased the necessity to replace hazardous processes and non-renewable resources with sustainable bioresources and green technologies [1,2]. In such contest, the biomass coming from lignocellulose can be considered as a starting material to obtain chemicals and sustainable fuels: indeed, it is biodegradable, renewable, quite available and low cost [3-6].

According to Figure 1, lignocellulose consists of 15\%-20\% lignin, 25\%-35\% hemicellulose and $40 \%-50 \%$ cellulose [3,7]. Lignin is made up of methoxylatedphenylpropane and it has a three dimensional structure, which bestows structural stiffness to plants and that surrounds hemicellulose [3,7-9]. Hemicellulose is a polymer and it is composed of C5 and C6 sugar monomers such as D-xylose, D-galactose, D-arabinose, D-glucose and D-manose [3,7-9]. The xylose monomer is the most abundant. Moreover, a polymeric xylan can be recovered from the hemicellulose fraction, and this polymer can be converted to a xylose monomer through diluted acid hydrolysis (for instance sulfuric acid) [7-9]. Finally, cellulose is a polymer made up of glucose units linked by $\beta$-glycosidic bonds [3,7]. Even though cellulose is the most copious material resource coming from plants, its employment is restricted due to its complex nature and rigid structure $[7,10]$. The majority of technological methodologies for the conversion of lignocellulosic stuff into chemicals and fuels are devoted to a pretreatment that allows obtaining cellulose from lignin and breaking down its rigid structure [7-9]. Afterward, by employing sulfuric acid as a catalyst, the cellulose material can be hydrolyzed into glucose monomers at high temperature [7]. The conversion of these feedstocks into value-added 
products can be conceived by sequential transformations of determined molecules coming from biomass, the so-called platform molecules [3]. The determination of such molecules was carried out by the US Department of Energy (DOE) [11] and renewed in recent times by Bozell and Petersen [12]. These platform molecules encompass sugars (glucose and xylose), polyols (sorbitol, xylitol, and glycerol), furans (furfural, and 5-hydroxymethylfurfural) and acids (succinic, levulinic, and lactic acids) [7]. They were chosen based on the availability of commercial technologies for their production and on the possibility of converting them into fuels and chemicals inside biorefineries. As a starting material, platform molecules are functionalized compounds; this implies that their transformation into more valuable chemicals requires a lower number of steps than those needed from essentially unfunctionalized alkanes coming from fossil reserves [7]. Even though biomass represents a unique reservoir for obtaining chemicals instead of the employment of fossil fuels, the biofuel production starting from renewable biomass has attracted more interest than the production of chemicals because of the strategic value of the transportation sector in our society, which is essentially based on the use of nonrenewable petroleum [4-7].

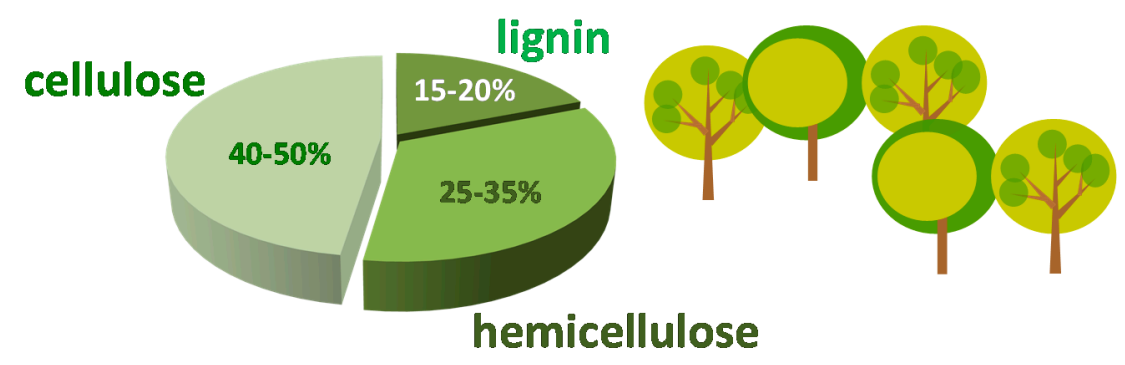

Figure 1. Composition of biomass.

To efficiently convert lignocellulosic biomass into fuels and chemicals, both C5 and C6 fractions (hemicellulose and cellulose, respectively) have to be employed. However, the biological conversion of $\mathrm{C} 5$ sugars is not efficient and it requires the development of opportune strategies for its catalytic transformation. Moreover, the opportunity of producing value-added products is further strengthened by the fact that $\mathrm{C} 5$ sugars are also originated as side stream in the paper industrial production. Hence, a first challenge is to improve cost effective processes or novel catalysts to transform complex carbohydrate moieties into platform molecules $[13,14]$. Among the products that can be obtained from the $C 5$ fraction of lignocellulose, furfural represents a promising choice because, beside chemicals such as furfuryl alcohol and tetrahydrofurfuril alcohols, it can also displace organics from petroleum for the production of plastics, lubricants, resins and adhesives [15]. Therefore, much interest has been driven towards biomass-derived building block molecules, such as furfural, due to the need for renewables, fuels, fuel additives and chemicals [11].

\section{Furfural Oxidative Esterification to Methyl-2-furoate}

Furfural (2-FA) is a clear, colorless motile liquid with a characteristic "almond-benzaldehyde" odor. The molecular formula is $\mathrm{C}_{5} \mathrm{H}_{4} \mathrm{O}_{2}$. Its synonyms are: 2-furancarboxaldehyde, furaldehyde, 2-furanaldehyde, 2-furfuraldehyde, fural, and furfurol. Auto-oxidation occurs when exposed to sunlight in the presence of oxygen and it darkens to a dark red/brown color (Brenkem Consultants Asia Co., Nonthaburi, Thailand, 2004). Despite the number of efforts made recently to exploit cutting edge catalytic paths and methods to convert furfural into various high-density biosynthetic fuels $[8,15,16]$, the improvement of novel transformations that can enhance the number of actual routes for practical and cost effective furfural upgrading is still a very important theme of enormous industrial interest [17-19]. The use of furfural as a starting material could give rise to a number of chemicals including more than 1600 commercial products $[6,20]$. 
Actually, furfural has many different uses: it can be employed as a feedstock to produce gasoline, diesel, or jet fuel [21]. Other desired compounds such as furfuryl alcohol (via hydrogenation), furan (via decarbonylation) and tetrahydrofuran (via furan hydrogenation) can be obtained using furfural as a precursor [6]. Further furfural conversions are extremely needed [22]: among these, the synthesis of alkyl furoates by furfural oxidative esterification can open very intriguing routes for the use of xyloses. Furfural oxidative esterification with an alcohol in the presence of oxygen is reported in Scheme 1a. It has to be considered that the condensation reaction of furfural and aldehyde is also feasible to impel two carbon molecules together and produce longer hydrocarbon chains and low volatile liquids fuels [23]. Acetone and aldehydes can originate from the oxidation of secondary and primary alcohols in the presence of molecular oxygen [24]. Recently, in a study on the oxidative esterification of furfural and aliphatic alcohols using an $\mathrm{Au} / \mathrm{FH}$ catalyst (FH refers to $\mathrm{Fe}_{x} \mathrm{O}_{y}$-hydroxyapatite) with molecular oxygen and in the presence of a potassium carbonate, a 91.8\% yield of methyl-2-furoate with $98.7 \%$ selectivity were attained using methanol $\left(140{ }^{\circ} \mathrm{C}\right.$ for $4 \mathrm{~h}$ under $\left.0.3 \mathrm{MPa}_{2}\right)$, whereas $91.4 \%$ yield of 3-(furan-2-yl-)-2-methylacrylaldehyde with $92.7 \%$ selectivity were obtained using propanol [25].

a)<smiles>O=Cc1ccco1</smiles>

b)<smiles>O=Cc1ccco1</smiles>
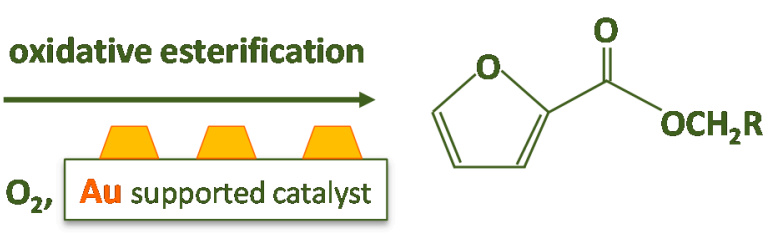

oxidative condensation
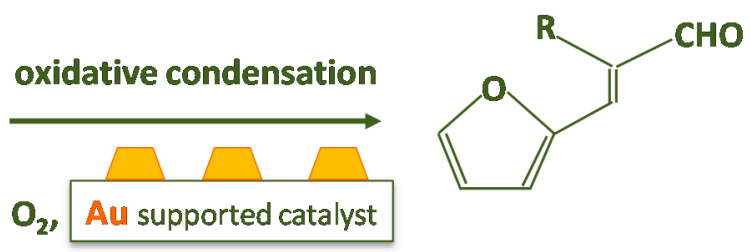

Scheme 1. Furfural oxidative esterification (a) and oxidative condensation (b) reactions.

It is worth noting that oxidative condensation and oxidative esterification are competitive reactions when considering a furfural-alcohol-oxygen system, as shown in Scheme 1.

In the present review, we focused on the furfural conversion to methyl-2-furoate, the formation of non-methyl esters should not be feasible because furfural does not possess acid protons in $\alpha$ position. Moreover, the product formation by competing oxidative condensation requires firstly the use of a base and the use of an alcohol with a chain of at least two carbon atoms (according to Scheme 1b). Indeed, alkyl furoates can be employed as extracting agents in many different industrial plants if produced in large quantities and at low price and, additionally, they find applications as flavor and fragrance component in the fine chemical industry. Usually, the ester is obtained by furfural oxidation with potassium permanganate, optionally employing acetone as solvent, and then the produced furoic acid is reacted with methyl or ethyl alcohol in the presence of sulfuric acid. The use of these substances has a strong negative impact on the environment. There have already been efforts to modify furfural-based derivatives by homogeneous catalysis [26].

Up to now, several examples dealing with the oxidation of 2-FA in the presence of heterogeneous catalysts have been reported [23-25,27-29]. These papers mainly deal with the use of gold supported catalysts [25,27-29] demonstrating the current efforts to modify furfural-based derivatives by gold catalysis, due to the fact that such supported metal systems are mainly used as suitable catalysts for selective oxidation. Indeed, gold currently is a hot spot in catalysis research [30,31]. Only since 1987, gold has been shown to be highly active if deposited as nanoparticles over oxidic supports [32]. Pioneering studies have put in evidence that surface adsorption and reactivity of gold can be increased 
by creating defective surface structures through downsizing of the gold nanoparticles. Very active catalysts are produced when gold nanoparticles with size below about $5 \mathrm{~nm}$ are supported on oxides. Indeed, nanoparticulated gold catalysts are active under mild conditions, even well below room temperature, and this feature makes them unequalled. Gold has been acknowledged as a very good catalyst for selective oxidation with molecular $\mathrm{O}_{2}$ when in the form of nanoparticles [33]. Several methods for the generation of suitably small sized gold particles have been tried and, among these, the deposition-precipitation $(\mathrm{dp})$ method is one of the most promising procedures. More in detail, the $\mathrm{dp}$ method involves raising the $\mathrm{pH}$ of a $\mathrm{HAuCl}_{4}$ solution by adding a base when the adsorption of the species in solution occurs and they can react with or be deposited on the support.

Taarning et al. showed that 2-FA can be converted into methyl-2-furoate by oxidative esterification under very mild reaction conditions in a relatively short time $\left(22^{\circ} \mathrm{C}, 1\right.$ bar oxygen, full conversion is accomplished in 10-12 h) in the presence of $\mathrm{NaCH}_{3} \mathrm{O}$ and $\mathrm{CH}_{3} \mathrm{OH}$ on the $\mathrm{Au} / \mathrm{TiO}_{2}$ reference catalyst provided by the World Gold Council (WGC) [27]. The produced methyl-2-furoate can easily be purified by distillation, offering an interesting and proficient way to convert furfural by using oxygen as the only stoichiometric agent [27].

The efficient condensation of furfural with $n$-propanol to prepare a furfural-containing long chain aldehyde has also been reported [25]. In particular, very high yield of methyl-2-furoate and selectivity were obtained by oxidative esterification in a furfural-methanol- $\mathrm{O}_{2}$ system in the presence of a $\mathrm{Au}$ $(5.0 \mathrm{wt} \%)$ catalyst and of $\mathrm{K}_{2} \mathrm{CO}_{3}$. Kegnæs et al. investigated the oxidative coupling of different alcohols and aldehydes with $N$-hexylamine to form the corresponding $N$-hexylamides [29]. Among the examined reactants, the authors found that furfural was oxidized to the corresponding methyl ester in high yields when supported nanoparticles $\left(\mathrm{Au} / \mathrm{TiO}_{2}\right.$ supplied by Mintek, with gold particles having 4-8 nm size) and a base (KOMe) were used as catalysts. However, the presence of the base would render the process less green and less effective from an economic point of view [28]. Corma et al. [28] reported on a base-free oxidative esterification of 5-hydroxymethyl-2-furfural into 2,5-dimethylfuroate on an $\mathrm{Au} / \mathrm{CeO}_{2}$ catalyst, but working at temperature and pressure higher than those employed in the activity test performed and reported in ref. [27]. The excellent oxidation activity displayed by $\mathrm{Au} / \mathrm{CeO}_{2}$ and its easy recovery and reusability were reported. It was found that the higher are the temperature and the amount of catalyst, the higher is the initial reaction rate. However, $100 \%$ yield is always obtained under different reaction conditions. More recently, the oxidative esterification of furfural to methyl-2-furoate was performed using methanol as a solvent and without the addition of $\mathrm{NaCH}_{3} \mathrm{O}$ (see Scheme 1a) [34]. Very good catalytic performances have been observed over a gold supported sulfated zirconia catalyst, especially if compared with the $\mathrm{Au} / \mathrm{TiO}_{2}$ reference catalyst. It was proposed that the enhanced activity was due to the presence of Au clusters able to dissociate $\mathrm{O}_{2}$ producing atomic $\mathrm{O}$ with basic properties that could activate $\mathrm{CH}_{3} \mathrm{OH}$ [34].

Nevertheless, a highly efficient and selective one-pot process involving the oxidative condensation and the hydrogenation of furfural with aliphatic alcohols catalyzed by metallic platinum has been reported very recently [23]. The authors examined several typical supported Pt catalysts and bases as catalysts for the reaction and found high conversion and selectivity when working in the presence of $5 \% \mathrm{Pt} / \mathrm{HT}$ ( $\mathrm{HT}=$ hydrotalcite $\mathrm{Mg} / \mathrm{Al}$ ratio equal to 3 ) and of potassium carbonate either in the furfural-ethanol- $\mathrm{O}_{2}$ system, or in the furfural- $n$-propanol- $\mathrm{O}_{2}$ one.

Novel cobalt-based catalysts have been employed for the direct oxidative esterification of benzylic alcohols to the corresponding methyl ester in methanol and using molecular oxygen as benign oxidant [35]. The $\mathrm{Co}_{3} \mathrm{O}_{4}$-N@C catalysts were obtained by pyrolysis of nitrogen-ligated cobalt (II) acetate supported on commercial carbon. The authors reported that cross and self-esterification of alcohols proceeded in the presence of the cobalt-containing material and of $\mathrm{K}_{2} \mathrm{CO}_{3}$ with good to excellent yields. More recently, Deng et al. studied similar pyrolysed complexes with a noble-metal-free approach and explored different metals (such as $\mathrm{Co}, \mathrm{Pd}, \mathrm{Mn}$ ) and ligands (such as 1,10 phenantroline and 2,2-dipyridine) to investigate the optimum catalytic efficiency in the esterification of furfural in methanol [36]. In this case, high yield and selectivity of methyl-2-furoate were also obtained under 
optimized conditions in the presence of the $\mathrm{Co}_{\mathrm{x}} \mathrm{O}_{\mathrm{y}}-\mathrm{N} @ \mathrm{C}$ catalyst and by adding a base. Reusability studies were also carried out and no significant loss of activity was detected up to five cycles.

The $\mathrm{N}$-heterocyclic carbene catalyzed esterification of a variety of aromatic aldehydes with alcohols under aerobic conditions was also reported [37]. The authors developed a simple and efficient organocatalytic procedure that allows obtaining high purity products in high yields.

Despite the use of molecular oxygen as benign oxidant, the majority of the reported studies involve the use of excess of base as co-catalyst of the reaction, as shown in Table 1, where the results obtained over different catalytic systems are summarized together with the employed reaction conditions. Table 1 also provides an overview on the best performing catalysts: high conversion and selectivity can be achieved in many cases. However, furfural esterification can be efficiently carried out over Au-based catalyst even without using a base as co-catalyst (see bold text in Table 1). Such systems appear to be the most promising catalyst for the production of alkyl furoates.

Table 1. Catalytic results and reaction conditions obtained over different catalysts.

\begin{tabular}{|c|c|c|c|c|c|c|c|c|c|}
\hline Catalyst & $\begin{array}{l}\text { Metal Loading } \\
\text { (wt \%) }\end{array}$ & $\begin{array}{c}\mathrm{O}_{2} \\
\text { (bar) }\end{array}$ & Alcohol & Base & $\begin{array}{c}\mathrm{T} \\
\left({ }^{\circ} \mathrm{C}\right)\end{array}$ & $\begin{array}{l}\text { Time } \\
\text { (h) }\end{array}$ & $\begin{array}{l}\text { Conversion } \\
(\%)\end{array}$ & $\begin{array}{c}\text { Selectivity } \\
\text { (or Yield, Y) (\%) a }\end{array}$ & Ref. \\
\hline $\mathrm{Pt} / \mathrm{FH}^{\mathrm{b}}$ & 5 & 3 & ethanol & none & 140 & 4 & 53.0 & 100 & [23] \\
\hline $\mathrm{Pt} / \mathrm{FH}^{\mathrm{b}}$ & 5 & 3 & ethanol & $\mathrm{K}_{2} \mathrm{CO}_{3}$ & 140 & 4 & 93.9 & 32.1 & [23] \\
\hline $\mathrm{Pt} / \mathrm{H}^{\mathrm{c}}$ & 5 & 3 & ethanol & $\mathrm{K}_{2} \mathrm{CO}_{3}$ & 140 & 4 & 92.5 & 31.3 & [23] \\
\hline $\mathrm{Pt} / \mathrm{HTc}^{\mathrm{d}}$ & 5 & 3 & ethanol & $\mathrm{K}_{2} \mathrm{CO}_{3}$ & 140 & 4 & 97.2 & 30.9 & [23] \\
\hline $\mathrm{Pt} / \mathrm{Fe}_{3} \mathrm{O}_{4}$ & 5 & 3 & ethanol & $\mathrm{K}_{2} \mathrm{CO}_{3}$ & 140 & 4 & 93.8 & 28.8 & [23] \\
\hline $\mathrm{Pt} / \mathrm{Al}_{2} \mathrm{O}_{34}$ & 5 & 3 & ethanol & $\mathrm{K}_{2} \mathrm{CO}_{3}$ & 140 & 4 & 97.1 & 31.4 & [23] \\
\hline $\mathrm{Pt} / \mathrm{ZrO}_{2}$ & 5 & 3 & ethanol & $\mathrm{K}_{2} \mathrm{CO}_{3}$ & 140 & 4 & 58.9 & 18.7 & [23] \\
\hline $\mathrm{PtO}_{\mathrm{x}} / \mathrm{HTc}^{\mathrm{d}}$ & 5 & 3 & ethanol & $\mathrm{K}_{2} \mathrm{CO}_{3}$ & 140 & 4 & 33.7 & 52.0 & [23] \\
\hline $\mathrm{Pt} / \mathrm{FH}^{\mathrm{b}}$ & 5 & 3 & $n$-propanol & none & 140 & 4 & 46.3 & 100 & [23] \\
\hline $\mathrm{Pt} / \mathrm{FH}^{\mathrm{b}}$ & 5 & 3 & $n$-propanol & $\mathrm{K}_{2} \mathrm{CO}_{3}$ & 140 & 4 & 90.1 & 10.0 & [23] \\
\hline $\mathrm{Pt} / \mathrm{H}^{\mathrm{c}}$ & 5 & 3 & $n$-propanol & $\mathrm{K}_{2} \mathrm{CO}_{3}$ & 140 & 4 & 73.0 & 9.9 & [23] \\
\hline $\mathrm{Pt} / \mathrm{HTC}^{\mathrm{d}}$ & 5 & 3 & $n$-propanol & $\mathrm{K}_{2} \mathrm{CO}_{3}$ & 140 & 4 & 87.8 & 11.5 & [23] \\
\hline $\mathrm{Pt} / \mathrm{Fe}_{3} \mathrm{O}_{4}$ & 5 & 3 & $n$-propanol & $\mathrm{K}_{2} \mathrm{CO}_{3}$ & 140 & 4 & 80.6 & 8.9 & [23] \\
\hline $\mathrm{Pt} / \mathrm{Al}_{2} \mathrm{O}_{34}$ & 5 & 3 & $n$-propanol & $\mathrm{K}_{2} \mathrm{CO}_{3}$ & 140 & 4 & 81.4 & 9.6 & [23] \\
\hline $\mathrm{Pt} / \mathrm{ZrO}_{2}$ & 5 & 3 & $n$-propanol & $\mathrm{K}_{2} \mathrm{CO}_{3}$ & 140 & 4 & 31.9 & 10.0 & [23] \\
\hline $\mathrm{PtO}_{\mathrm{x}} / \mathrm{HTC}^{\mathrm{d}}$ & 5 & 3 & $n$-propanol & $\mathrm{K}_{2} \mathrm{CO}_{3}$ & 140 & 4 & 33.7 & 46.6 & [23] \\
\hline $\mathrm{Au} / \mathrm{FH}^{\mathrm{b}}$ & 5 & 3 & methanol & $\mathrm{K}_{2} \mathrm{CO}_{3}$ & 140 & 4 & 93 & 99 & [25] \\
\hline $\mathrm{Au} / \mathrm{H}^{\mathrm{c}}$ & 5 & 3 & methanol & $\mathrm{K}_{2} \mathrm{CO}_{3}$ & 140 & 4 & 48 & 93 & [25] \\
\hline $\mathrm{Au} / \mathrm{Fe}_{3} \mathrm{O}_{4}$ & 5 & 3 & methanol & $\mathrm{K}_{2} \mathrm{CO}_{3}$ & 140 & 4 & 41 & 82 & [25] \\
\hline $\mathrm{Au} / \mathrm{CeO}_{2}$ & 5 & 3 & methanol & $\mathrm{K}_{2} \mathrm{CO}_{3}$ & 140 & 4 & 55 & 82 & [25] \\
\hline $\mathrm{Au} / \mathrm{TiO}_{2}$ & 1 & 1 & methanol & $\mathrm{NaCH}_{3} \mathrm{O}$ & 22 & $10-12$ & 100 & 100 & [27] \\
\hline $\mathrm{Au} / \mathrm{CeO}_{2}{ }^{\mathrm{e}}$ & 2.1 & 10 & methanol & none & 130 & 2 & $>99$ & $91(\mathrm{Y})$ & [28] \\
\hline $\mathrm{Au} / \mathrm{Fe}_{2} \mathrm{O}_{3} \mathrm{f}$ & 4.5 & 10 & methanol & none & 130 & 24 & 94 & $6.2(\mathrm{Y})$ & [28] \\
\hline $\mathrm{Au} / \mathrm{TiO}_{2} \mathrm{f}$ & 1 & 10 & methanol & none & 130 & 24 & $>99$ & $96.3(\mathrm{Y})$ & [28] \\
\hline$A \mathbf{u} / \mathbf{C}^{\mathrm{f}}$ & 1.5 & 10 & methanol & none & 130 & 24 & 96 & $7.6(\mathrm{Y})$ & [28] \\
\hline $\mathrm{Au} / \mathrm{CeO}_{2}{ }^{\mathrm{f}}$ & 1 & 10 & methanol & none & 130 & 5 & $>99$ & $>99(\mathrm{Y})$ & {$[28]$} \\
\hline $\mathrm{Au} / \mathrm{TiO}_{2} \mathrm{e}$ & 1 & $\sim 1$ & methanol & $\mathrm{KCH}_{3} \mathrm{O}$ & 25 & 24 & 100 & $>99(\mathrm{Y})$ & [29] \\
\hline $\mathrm{Au} / \mathrm{ZrO}_{2}$ & 1.51 & 6 & methanol & none & 120 & 1.5 & 100 & 100 & [34] \\
\hline $\mathrm{AuTiO}_{2}$ & 1.56 & 6 & methanol & none & 120 & 3 & 90 & 65 & [34] \\
\hline $\mathrm{Co}_{3} \mathrm{O}_{4}-\mathrm{N} @ \mathrm{C}^{\mathrm{e}}$ & 3 & 1 & methanol & $\mathrm{K}_{2} \mathrm{CO}_{3}$ & 70 & 24 & 100 & $77(\mathrm{Y})$ & [35] \\
\hline $\mathrm{Co}(1,10$-phen $) / \mathrm{C}$ & 3 & 1 & methanol & $\mathrm{K}_{2} \mathrm{CO}_{3}$ & 60 & 12 & 100 & $95(\mathrm{Y})$ & [36] \\
\hline $\operatorname{Pd}(1,10$-phen $) / C$ & 3 & 1 & methanol & $\mathrm{K}_{2} \mathrm{CO}_{3}$ & 60 & 12 & 12 & $4(\mathrm{Y})$ & [36] \\
\hline $\operatorname{Co}(2,2-\mathrm{diPy}) / \mathrm{C}$ & 3 & 1 & methanol & $\mathrm{K}_{2} \mathrm{CO}_{3}$ & 60 & 12 & 58 & $46(\mathrm{Y})$ & [36] \\
\hline $\operatorname{Co}(1,10$-phen $) / C^{e}$ & 3 & 1 & methanol & $\mathrm{K}_{2} \mathrm{CO}_{3}$ & 60 & 12 & 54 & $42(\mathrm{Y})$ & [36] \\
\hline $\operatorname{Mn}(1,10$-phen $) / C^{e}$ & 3 & 1 & methanol & $\mathrm{K}_{2} \mathrm{CO}_{3}$ & 60 & 12 & 9 & - & [36] \\
\hline $\operatorname{Pd}(1,10$-phen $) / \mathrm{C}^{\mathrm{e}}$ & 3 & 1 & methanol & $\mathrm{K}_{2} \mathrm{CO}_{3}$ & 60 & 12 & 15 & $1(\mathrm{Y})$ & [36] \\
\hline NHC $\mathrm{g}$ & none & $\sim 1$ & methanol & $\mathrm{DBU}^{\mathrm{h}}$ & 25 & - & 24 & $63(\mathrm{Y})$ & [37] \\
\hline
\end{tabular}

a Selectivity (or reported yield, $\mathrm{Y}$ ) to the ester; ${ }^{\mathrm{b}} \mathrm{FH}=\mathrm{Fe}_{\mathrm{x}} \mathrm{O}_{\mathrm{y}}$-hydroxyapatite; ${ }^{\mathrm{c}} \mathrm{H}=$ hydroxyapatite;

d HTc = calcined hydrotalcite; e reactant: furfuryl alcohol; ${ }^{\mathrm{f}}$ reactant: 5-hydroxymethyl-2-furfural;

${ }^{\mathrm{g}} \mathrm{NHC}=\mathrm{N}$-heterocyclic carbene; ${ }^{\mathrm{h}} \mathrm{DBU}=1,8$-Diazabicyclo[5.4.0] undec-7-ene.

\section{On the Reaction Mechanism}

Generally, aldehyde oxidation occurs either in the presence of water (yielding the acid) or in the presence of an alcohol (giving the ester). This suggests a hemiacetal species as intermediate when 
alcohol is used. However, the reaction takes place much more readily than alcohol oxidation rendering not possible to study when the reaction is started from the alcohol. A series of experiments was carried out by Fristrup et al. in order to study the influence of electronic effects in the substrate on the reaction rate have investigated the mechanism for the aerobic oxidation of selected para-substituted benzaldehydes to methyl esters by carrying out the reaction in methanol [38] In all cases, a kinetic of the first order was found. Moreover, a radical mechanism is operating in the case of substrates with electron-withdrawing substituents $\left(\mathrm{X}=\mathrm{Cl}, \mathrm{CF}_{3}, \mathrm{CN}\right.$ and $\left.\mathrm{COOMe}\right)$ whereas for substrates with electron-donating substituent a low reactivity is expected and a radical mechanism is not operating. Moreover, by combining kinetic isotope effect determinations, the authors put in evidence that proton abstraction from benzaldehyde is the rate-determining step. When labeled methanol was employed, the amount of produced labeled methyl ester was markedly larger than that of the un-labeled ester, indicating that the additional oxygen functionality present in the product ester comes from methanol rather than from molecular, which can be compatible with reversible formation of the hemiacetal prior to the proton abstraction [38].

A reasonable pathway for the furfural oxidative esterification reaction carried out in methanol has been proposed previously for gold supported on ceria nanoparticles [28]. In that paper, the authors showed that 5-hydroxymethyl-2-furfural was selectively converted into 2,5-dimethylfuroate with a $99 \mathrm{~mol} \%$ yield under mild conditions $\left(65-130^{\circ} \mathrm{C}\right.$ and 10 bar $\left.\mathrm{O}_{2}\right)$ without using any base. Moreover, the effect of the presence of different substituents in the 5-furane on the oxidation rate related to the 2-hydroxymethyl group was evaluated. It was found that the presence of ring deactivating groups, such as dimethoxymethyl and methylcarboxy, induces a decrease in the activity (74.6 and $72 \mathrm{~mol} \%$ yields, respectively) when using 4-substituted-benzyl alcohol substrates. Interestingly, $91 \mathrm{~mol} \%$ yield was obtained when no ring substituent was present and it was proposed that the reaction proceeds through an oxidation-esterification pathway. The capability of the chosen $\mathrm{Au} / \mathrm{CeO}_{2}$ system to selectively catalyze: (i) the oxidation of the hemiacetal into ester and the oxidation of the alcohol into aldehyde; rather than (ii) the reoxidation of the acetal into the ester, was suggested. Process (i) is thermodynamically favored due to the high stability of acetal. It was also found that the limiting step of the oxidative pathway is the alcohol oxidation to aldehyde. Once the aldehyde is formed the reaction proceeds through the formation of the hemiacetal and then the hemiacetal is oxidized into the ester. The authors proposed that, first, the furfural molecule is converted into the hemiacetal intermediate. Such compound is not noticeable by a gas chromatographic analysis. After that, two different routes can be suggested: the former implicates the hemiacetal direct oxidation into the methyl-2-furoate (furoate); on the other hand, the latter provides for the first transformation of the hemiacetal in the corresponding 2-furaldehyde-dimethyl-acetal (acetal). The acetal can then lead to the furoate. Moreover, the authors found that, according to the literature, the alcohols oxidation step is facilitated when a furane-ring activation function is present in position 5 [28]. In order to explain and to corroborate the pathway of the oxidative esterification, several tests were performed under the following reaction conditions: catalyst $(100 \mathrm{mg})$, furfural $(300 \mu \mathrm{L})$ with oxygen $(0.5-6$ bar, relative pressure) without $\mathrm{NaCH}_{3} \mathrm{O}$ addition at a proper temperature in the range $60-140{ }^{\circ} \mathrm{C}$ [39]. The tests were carried out on a $\mathrm{Au} / \mathrm{ZrO}_{2}$ catalyst $(1.22 \mathrm{wt} \% \mathrm{Au}$, prepared by dp) and are summarized in the following:

(i) Firstly, the reaction was performed without the catalyst (Scheme 2). Therefore, furfural, n-octane, methanol and 6 bar of $\mathrm{O}_{2}$ were charged in the autoclave. No traces of furoate, acetal or other products were detected after $3 \mathrm{~h}$ of reaction at $120^{\circ} \mathrm{C}$, indicating that the catalyst is needed for performing the reaction.

(ii) Another test was carried out in the presence of the $\mathrm{Au} / \mathrm{ZrO}_{2}$ catalyst by adopting the usual reaction conditions, but employing furoic acid as substrate instead of furfural (see Scheme 3). The aim was to rule out the furoate formation via furoic acid. No furoate was formed during such test. 
(iii) The third test involved the use of bare zirconia (either plain zirconia or sulfated zirconia), instead of employing the $\mathrm{Au} / \mathrm{ZrO}_{2}$ catalyst (Scheme 4). The autoclave was charged as usual and the typical reaction conditions were chosen. Furfural was totally converted $(100 \%)$; nevertheless, only acetal was produced, possibly due to the Lewis acidity displayed by zirconia $[40,41]$.

These results put in evidence that the gold active phase is needed to produce the desired furoate.

(iv) The solution was filtered and separated from zirconia after the test at point (iii) and performed in the presence of the bare support. Then the solution of acetal in methanol was charged in the autoclave in the presence of the $\mathrm{Au} / \mathrm{ZrO}_{2}$ catalyst in order to verify if the acetal molecule can be converted in the furoate over the catalyst under reaction conditions. According to Scheme 5, only acetal was found after the catalytic test. Hence, the results indicate that furfural can be converted into acetal in the presence of the bare support, but acetal, due to its stability, cannot be transformed into the desired furoate.

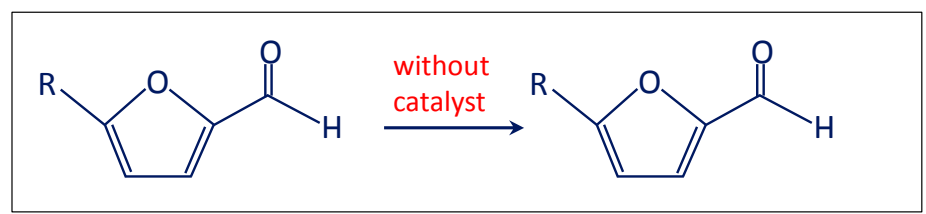

Scheme 2. Test performed to investigate the mechanism for the oxidative esterification of furfural $(\mathrm{R}=-\mathrm{H})$.

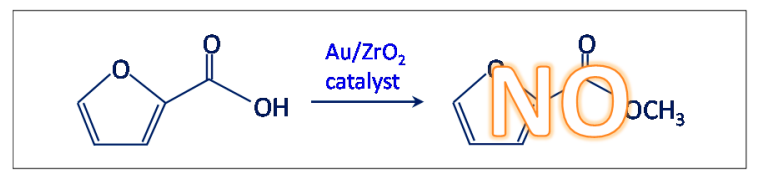

Scheme 3. Test performed to investigate the mechanism for the oxidative esterification of furfural $(\mathrm{R}=-\mathrm{H})$.

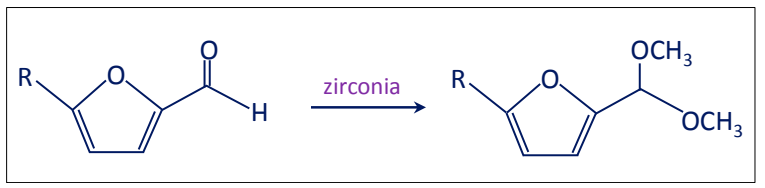

Scheme 4. Test performed to investigate the mechanism for the oxidative esterification of furfural $(\mathrm{R}=-\mathrm{H})$.

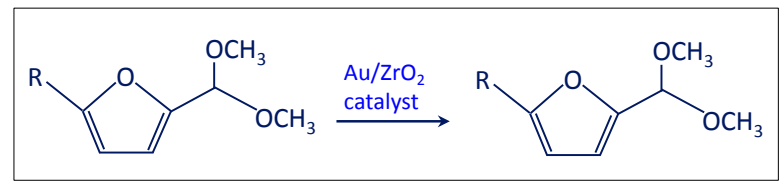

Scheme 5. Test performed to investigate the mechanism for the oxidative esterification of furfural $(\mathrm{R}=-\mathrm{H})$.

The catalytic tests demonstrated that the reaction pathway involved the direct selective oxidation of furfural to the desired furoate over $\mathrm{Au} / \mathrm{ZrO}_{2}$. In addition, the presence of the $\mathrm{Au} / \mathrm{ZrO}_{2}$ catalyst assures the nearly total selectivity to methyl-2-furoate. At the same time, the reaction proceeds with the acetal formation in the presence of the bare support. The acetal molecule is stable under reaction conditions and it cannot be further converted. As a consequence, it has been shown that the gold active 
phase is needed to obtain the desired furoate. Further FTIR experiments confirmed that the furoate molecule is formed without production of any adsorbed intermediate species. Moreover, the FTIR spectra indicated that the reaction occurred through the direct selective oxidation of furfural to the desired furoate in the presence of $\mathrm{Au} / \mathrm{ZrO}_{2}$, as previously discussed (see Scheme 3) [39]. Finally, the spectroscopic measures put in evidence that the reaction proceeds over the $\mathrm{Au} / \mathrm{ZrO}_{2}$ catalyst already at room temperature and that the selectivity to methyl-2-furoate is almost complete. A reaction order of 1 with respect to furfural was obtained. In addition, the activation energy was determined and a value of $38.9 \mathrm{~kJ} / \mathrm{mol}$ was calculated, therefore excluding any possible influence of pore diffusion in the kinetic data [39]. Interestingly, high conversions, as good as those obtained by using pure oxygen, were achieved when a relative low pressure of air ( 0.5 bar) was employed instead of oxygen, therefore improving significantly the process and the same time high conversion and selectivity were maintained [39]. Moreover, great advantages in terms of safety of the plant can be achieved by substituting oxygen with air, because the relative air pressure permitted to carry out the reaction outside the explosion limits [42]. In this way, the risks for operators are eliminated and the costs due to the plant management are diminished, in a perspective of future applications.

In regard to selectivity, a strong effect displayed by the nanostructure of ceria supports (nanoparticles, rod-like particles and cubic-shaped particles) for gold nanoparticles is observed when $\alpha, \beta$-unsaturated aldehydes are employed in the reaction with methanol [43]. In particular, methyl acrylate and 3-methoxy propanal in different ratios were detected in the presence of the different ceria supports and a $100 \%$ selectivity to methyl methacrylate for all catalysts was found when methacrolein was used instead of acrolein. The conversion was the highest in the case of gold on ceria nanoparticles and the lowest on the cube-ceria. Finally, the selectivity to methyl 2-butenoate was 100\% for Au on ceria nanoparticles and rods, whereas a $100 \%$ selectivity to 3-methoxybutanal was observed for $\mathrm{Au} /$ ceria cubes in the crotonaldehyde-methanol reaction. The authors ascribed the differences arisen from the structure of the $\alpha, \beta$-unsaturated aldehydes to the oxygen activity or reactivity on the surface together with the influence of the methyl group on the reactivity of the aldehyde hydrogen and the inhibition of $\mathrm{CH}_{3} \mathrm{O}-\mathrm{H}$ addition reactions [43].

\section{Role of the Gold Size}

The size of gold nanoparticles is one of the key parameter ruling the catalytic activity. Indeed, it is well known that gold displays unique properties when in the form of nanometric particles [44-48]. Beside the most extensively studied reactions, such as CO oxidation and preferential oxidation [49-51], supported gold nanoparticles have been employed to catalyze a variety of processes such as C-C coupling reactions [52], reduction of organic compounds [53,54] as well as aerobic oxidative reactions [55-58]. Recently, Au-based supported metal nanoparticles have extensively investigated as catalysts for the selective oxidation of alcohols [59-62]. In particular, as for the oxidative esterification of alcohol to methyl esters, Christensen et al. described a practically, and potentially economically, attractive route to furnish esters starting from aldehydes. They for example oxidized acrolein-aldehyde of allyl alcohol, in methanol under oxygen atmosphere using commercial $\mathrm{Au} / \mathrm{TiO}_{2}(1 \%$, supplied by Mintek) supported on titanium oxide, producing methyl acrylate with $87 \%$ selectivity at $97 \%$ conversion in the presence of NaOMe [63]. Unfortunately, no relationship between the extremely high activity and the Au size was found by the authors [27,63]. Corma et al. [28] compared several gold catalysts on different supports, but with similar gold particle size in the oxidative esterification of 5-hydroxymethyl-2-furfural into 2,5-dimethylfuroate and found that Au supported on nanoparticulated ceria gave the best performances. The same research group performed a systematic study on the influence of the Au particle size and the gold content on the support: a linear relationship between the activity and the total number of external gold atoms was established [57]. Analogously, the promising results obtained in ref. [25] as for the transformation of furfural with aliphatic alcohols in the presence of molecular oxygen (and of a base) were ascribed to the small average of the supported gold nanoparticles. 
The role of gold dispersion on the catalytic properties of supported gold nanoparticles in the furfural selective oxidation to methyl-2-furoate was investigated by Pinna et al. [34]. It was found that the catalysts were able to work without adding $\mathrm{NaCH}_{3} \mathrm{O}$ and that the most promising performances were displayed by highly dispersed gold. Moreover, the presence of nanoparticles larger than $4 \mathrm{~nm}$ makes the catalyst poorly active and selective. The same research group carried out a systematic investigation on the role of the gold size in $\mathrm{Au} / \mathrm{ZrO}_{2}$ systems in a study dealing with the furfural oxidative esterification to methyl-2-furoate under mild conditions $\left(120^{\circ} \mathrm{C}, 6\right.$ bar $\left.\mathrm{O}_{2}\right)$ and without adding a base [64]. The $\mathrm{Au} / \mathrm{ZrO}_{2}$ catalysts were calcined at different temperatures in order to modulate the gold nanosize given the same metal loading.

It is worth noting that zirconia possesses many interesting properties such as redox properties, tuneable porosity and surface area that make it an appealing material to be used as a catalytic support. A support containing Lewis acid sites has been proven to be suitable to obtain gold active catalysts in the oxidation and esterification of 5-hydroxymethyl-2-furfural without adding a base [28]. In this frame, the surface acidity/basicity of zirconia can be opportunely tuned by adding different dopants. Therefore, sulfates were added to zirconia due to a double advantage: (i) the former is the higher gold dispersion because of the higher surface area of zirconia and (ii) the latter is the higher gold dispersion due to the presence of $\mathrm{SO}_{4}{ }^{2-}$ groups that play a positive role in addressing the metal to deposit as highly dispersed Au clusters in close contact with the support. As a consequence, the Au dispersion of $\mathrm{Au} / \mathrm{ZrO}_{2}$ was higher than that accomplished by using bare zirconia [65]. The obtained samples were differently colored depending on the temperature of calcination to which they have been submitted (Figure 2).

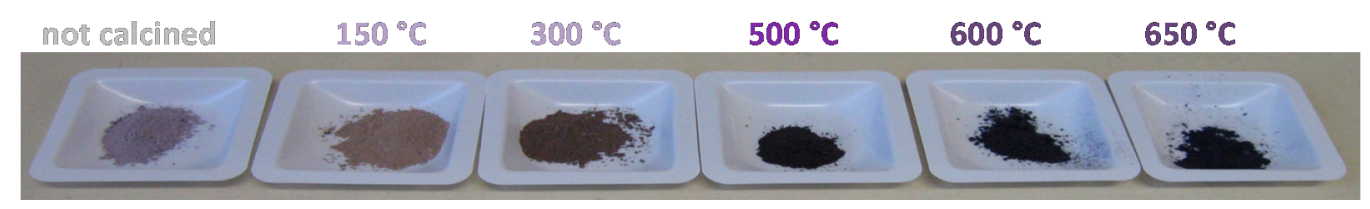

Figure 2. $\mathrm{Au} / \mathrm{ZrO}_{2}$ catalysts calcined at different temperature.

As far as $\mathrm{Au} / \mathrm{ZrO}_{2}$ calcined at $150{ }^{\circ} \mathrm{C}$ and at $300{ }^{\circ} \mathrm{C}$, High Resolution Transmission Microscopy (HRTEM) analysis revealed narrow and symmetric particle size distributions, indicating that the size is homogeneous and ranges between 1 and $2 \mathrm{~nm}$ and the presence of very small particles with size of $0.7 \mathrm{~nm}$ [64]. Very small particles and clusters were simultaneously observed with larger particles on the catalyst submitted to a calcination at $500^{\circ} \mathrm{C}$, resulting in a gold average size of $2.7 \pm 0.7 \mathrm{~nm}$. The calcination at $600{ }^{\circ} \mathrm{C}$ and $650^{\circ} \mathrm{C}$ lead to the total vanishing of the small particles and clusters. Concerning the oxidative esterification of furfural, the three samples calcined until $500{ }^{\circ} \mathrm{C}$ showed very promising conversion ( $98 \%-99 \%$ ) and selectivity ( $94 \%-98 \%$ ). On the contrary, $\mathrm{Au} / \mathrm{ZrO}_{2}$ calcined at $600{ }^{\circ} \mathrm{C}$ and $\mathrm{Au} / \mathrm{ZrO}_{2}$ calcined at $650{ }^{\circ} \mathrm{C}$ had visibly lower performances $(57 \%$ and $24 \%$ conversion, respectively, and $76 \%$ and $60 \%$ selectivity, respectively).

A plausible interpretation of such trend was the presence very small clusters (with size well below $0.7 \mathrm{~nm}$ and not noticeable by HRTEM) on the $\mathrm{Au} / \mathrm{ZrO}_{2}$ samples calcined at $150{ }^{\circ} \mathrm{C}$ and at $300{ }^{\circ} \mathrm{C}$, because of the low temperature of calcination to which the catalysts were submitted during preparation. Previous experimental results related to the epoxidation of propylene and of styrene [66,67], pointed out that there is a limiting size $(1.5-2 \mathrm{~nm})$ that differentiates the active catalysts from the inactive ones. Such limiting size seems associated to an intrinsic alteration of the properties of the Au clusters if compared to those related to the nanoparticles. It has been reported that gold clusters, supported on chemically and electronically inert materials, are able to adsorb and activate $\mathrm{O}_{2}$. O adatoms are probably produced and these species can start the partial oxidation reaction [68]. The interplay between the atomic oxygen and the highly dispersed clusters could be more robust than that occurring on the bigger nanoparticles observed on the catalyst submitted to calcination at $500{ }^{\circ} \mathrm{C}$. These findings 
definitely indicate that the choice of the calcination temperature is crucial to adjust conveniently the gold nanosize.

$\mathrm{CO}$ chemisorption is described as $\mathrm{mol}_{\mathrm{CO}} / \mathrm{mol}_{\mathrm{Au}}$ ratio and it gives information on the number of uncoordinated gold sites that are able to absorb CO [69]. Such uncoordinated sites could be possibly engaged in the activation of oxygen, too. It is possible to compare directly all samples through the $\mathrm{mol}_{\mathrm{CO}} / \mathrm{mol}_{\mathrm{Au}}$ ratio, because it is related to the number of moles of gold present in each sample. As a result, it was demonstrated that the $\mathrm{CO}$ chemisorption provides information on the degree of gold dispersion [69]. Generally, the achievement of a high $\mathrm{mol}_{\mathrm{CO}} / \mathrm{mol}_{\mathrm{Au}}$ ratio can be definitely associated to the presence of clusters, which expose a large number of uncoordinated sites. On the contrary, it was found that the $\mathrm{Au} / \mathrm{ZrO}_{2}$ catalysts submitted to thermal treatment at $600{ }^{\circ} \mathrm{C}$ and $650{ }^{\circ} \mathrm{C}$ possess low $\mathrm{mol}_{\mathrm{CO}} / \mathrm{mol}_{\mathrm{Au}}$ ratios (0.011 and 0.009 , respectively), signaling the existence of large gold particles on these samples. Finally, the samples calcined at $150{ }^{\circ} \mathrm{C}$ and $300{ }^{\circ} \mathrm{C}$ showed high chemisorption capability ( 0.651 and $0.320 \mathrm{~mol}_{\mathrm{CO}} / \mathrm{mol}_{\mathrm{Au}}$, respectively) indicating that Au clusters are present, whilst the $\mathrm{mol}_{\mathrm{CO}} / \mathrm{mol}_{\mathrm{Au}}$ ratio reported for $\mathrm{Au} / \mathrm{ZrO}_{2}$ treated at $500{ }^{\circ} \mathrm{C}$ was lower (0.027). This feature was related to the presence of either small Au nanoparticles or clusters.

The above results were in agreement with the drastic decrease of activity observed when the temperature of the calcination to which the samples were submitted is higher than $500{ }^{\circ} \mathrm{C}$. Indeed, at $\mathrm{T}>500{ }^{\circ} \mathrm{C}$, coalescence of all Au clusters present at the surface took place and nanoparticles are produced, as revealed by the data coming from either CO chemisorption or HRTEM analyses. Hence, it is possible to delimit an optimal range for Au mean size for the furfural oxidative esterification reaction, which ranges between 2 and $3.5 \mathrm{~nm}$ (Figure 3). The upper limit for a gold active size can be due to the intrinsic modification of the properties of Au clusters if compared to those of nanoparticles, as already described. Indeed, atomic O species can be produced on Au clusters upon molecular oxygen activation, therefore increasing the catalytic activity in the furfural oxidative esterification. However, there is also a lower limit for gold size: the interaction among the smallest clusters and atomic oxygen is too strong and therefore the catalyst activates oxygen less efficiently. It was demonstrated that polymer-incarcerated gold clusters with size around $1 \mathrm{~nm}$ were highly active and selective in the aerobic oxidative esterification of alcohols [70]. Among the several reactions screened in the paper, it was shown that aromatic alcohols containing both electron-donating and -withdrawing groups were effectively converted to the corresponding methyl-esters in good to high yields. Moreover, 2-pyridil methanol and cinnamyl alcohol were also selectively oxidized to the corresponding esters. All reactions were performed with the addition of potassium carbonate, indicating that such catalytic system needed the presence of a co-catalyst and that the presence of very highly dispersed gold is not sufficient to guarantee the high activity, according to the proposed lower limit for the gold size.

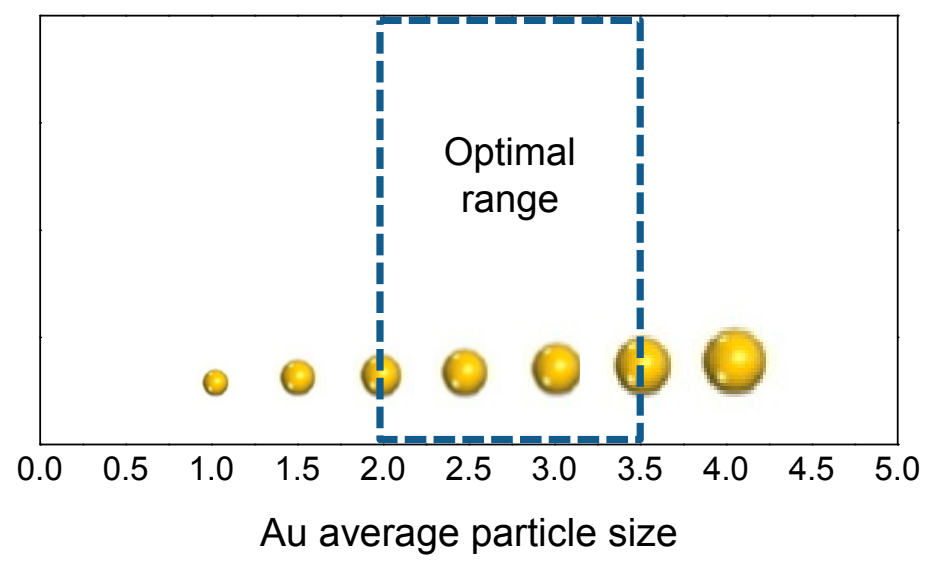

Figure 3. Optimal range for gold mean size in $\mathrm{Au} / \mathrm{ZrO}_{2}$ catalysts for 2-FA oxidative esterification to methyl-2-furoate. 
The above observations are in good agreement with previous results [34] and also with the data by Goodman et al. [71] collected for the $\mathrm{CO}$ oxidation reaction over an $\mathrm{Au} / \mathrm{TiO}_{2}$ catalyst, in which the maximum activity was displayed by Au species with size of $3.5 \mathrm{~nm}$. In that case, the enhanced reactivity appeared connected to the $\mathrm{Au}$ size and to a congenital change of the properties of $\mathrm{Au}$ clusters (able to activate molecular oxygen producing atomic $\mathrm{O}$ ) with respect to nanoparticles was also proposed [34,64].

In addition, the $\mathrm{Au}$ particle size distribution of $\mathrm{Au} / \mathrm{ZrO}_{2}$ calcined at $500{ }^{\circ} \mathrm{C}$ appeared significantly enlarged if compared to those obtained for the samples calcined at $150{ }^{\circ} \mathrm{C}$ and at $300{ }^{\circ} \mathrm{C}$ and gold particles with size between 1.5 and $4.5 \mathrm{~nm}$ were observed [64]. Nevertheless, the particle size distribution indicated that many very small particles with size below $2.5 \mathrm{~nm}$ were still present on the sample. This feature indicated that the gold dispersion was not compromised by the thermal treatment at high temperature and that probably clusters and very small particles are still present with larger particles. This is confirmed by the fact that both conversion and selectivity to methyl-2-furoate were substantially maintained.

In order to recover supplementary information on the nature of the exposed Au sites present at the surface of the examined samples, $\mathrm{CO}$ was used as a probe and FTIR spectroscopy measurements were carried out. An intense and symmetric band at $2100 \mathrm{~cm}^{-1}$, due to $\mathrm{CO}$ adsorbed on $\mathrm{Au}^{0}$ uncoordinated sites of gold clusters and small nanoparticles [72], and a weak band a $2163 \mathrm{~cm}^{-1}$, assigned to CO on $\mathrm{Zr}^{4+}$ sites of the support [73] were observed on as prepared $\mathrm{Au} / \mathrm{ZrO}_{2}$ calcined at $300{ }^{\circ} \mathrm{C}$ upon $\mathrm{CO}$ adsorption at room temperature. The same experiment performed on the as prepared sample submitted to calcination at $500{ }^{\circ} \mathrm{C}$ gave rise to a band at $2102 \mathrm{~cm}^{-1}$, which appeared with different shape, i.e., asymmetric towards the low frequencies, and whose intensity was lower than that observed in the case of $\mathrm{Au} / \mathrm{ZrO}_{2}$ calcined at $300{ }^{\circ} \mathrm{C}$. The component at $2102 \mathrm{~cm}^{-1}$ was assigned to $\mathrm{CO}$ on $\mathrm{Au}^{0}$ sites exposed at the surface of nanoparticles [50,74], whereas the component at lower frequency was related to $\mathrm{CO}$ on $\mathrm{Au}^{0}$ uncoordinated sites of clusters and of small nanoparticles [72]. The very weak band a $2174 \mathrm{~cm}^{-1}$ was ascribed to $\mathrm{CO}$ on $\mathrm{Zr}^{4+}$ sites with different coordinative unsaturation [40,72]. Therefore, the spectroscopic measurements signaled that gold clusters are present not only on the catalyst calcined at $300{ }^{\circ} \mathrm{C}$, but also on that calcined at $500^{\circ} \mathrm{C}$, for which inconclusive HRTEM results were accomplished.

The results demonstrate that the catalytic activity in the furfural oxidative esterification to methyl-2-furoate is strictly connected to the metal dispersion. In particular, the presence of highly dispersed gold clusters able to produce atomic oxygen is required for good catalytic performances.

\section{Effect of the Nature of the Support}

\section{1. $\mathrm{ZrO}_{2}$ vs. $\mathrm{TiO}_{2}$ : A Comparison with the $\mathrm{Au} / \mathrm{TiO}_{2}$ Reference Catalyst Provided by the Worl Gold Council}

A comparison with the $\mathrm{Au} / \mathrm{TiO}_{2}$ reference sample provided by the World Gold Council [75] has been performed. For the sake of clarity, Table 2 summarizes the information related to the examined samples, such as the Au loading, the results obtained by $\mathrm{CO}$ chemisorption and the average size of gold obtained by HRTEM analyses [34]. Conversely, Table 3 shows conversion and selectivity to methyl-2-furoate.

Table 2. Examined catalysts.

\begin{tabular}{cccc}
\hline Catalyst & $\mathbf{A u}$ Loading (wt \%) & $\mathbf{m o l}_{\mathbf{C O}} / \mathbf{m o l}_{\mathbf{A u}}$ & $\mathbf{A u ~ S i z e ~ ( n m ) ~}$ \\
\hline $\mathrm{Au} / \mathrm{ZrO}_{2}$ & 1.56 & 0.190 & $1.68 \pm 0.38$ \\
$\mathrm{Au} / \mathrm{TiO}_{2}$ & 1.51 & 0.033 & $3.80 \pm 0.75$ \\
\hline
\end{tabular}


Table 3. Comparison between the catalytic performances at increasing time of reaction of $\mathrm{Au} / \mathrm{TiO}_{2}$ and $\mathrm{Au} / \mathrm{ZrO}_{2}$.

\begin{tabular}{ccccc}
\hline & $\mathrm{Au} / \mathrm{TiO}_{\mathbf{2}}$ & \multicolumn{2}{c}{$\mathrm{Au} / \mathbf{Z r O}_{\mathbf{2}}$} \\
\hline Time (min) & Conversion (\%) & Selectivity (\%) & Conversion (\%) & Selectivity (\%) \\
\hline 0 & - & - & - & - \\
30 & 35 & 79 & 35 & 98 \\
60 & 60 & 73 & 79 & 99 \\
90 & 72 & 73 & 96 & 99 \\
120 & 80 & 69 & 99 & 99 \\
150 & 82 & 66 & 99 & 99 \\
180 & 88 & & 100 & 100 \\
\hline
\end{tabular}

The furfural oxidative esterification was performed using methanol as a solvent and as a reactant and without the addition of $\mathrm{NaCH}_{3} \mathrm{O}$. Moreover, bland reaction conditions were employed $\left(120^{\circ} \mathrm{C}\right.$ and 6 bar) and as good as those described in the literature [28]. Methyl-2-furoate was the main product obtained. However, only acetal derivate was detected as by-product, as revealed by mass spectroscopy. The $\mathrm{Au} / \mathrm{ZrO}_{2}$ sample showed very good catalytic performances, because $100 \%$ conversion and $100 \%$ selectivity were achieved after 90 min reaction.

HRTEM analysis corroborated by quantitative $\mathrm{CO}$ chemisorption measurements as well as by FTIR spectroscopy of adsorbed $\mathrm{CO}$ indicated the presence of very small gold particles and clusters on $\mathrm{AuZrO}_{2}$ (see Table 2). As already discussed in Section 2, highly dispersed Au species, on which highly basic $\mathrm{O}$ atoms are produced by $\mathrm{O}_{2}$ dissociation, have a key role in the 2-FA esterification reaction and can justify the differences observed in terms of activity and selectivity (summarized in Table 3). It is worth noting that these gold species are active, even without the addition of a base $\left(\mathrm{NaCH}_{3} \mathrm{O}\right)$.

On the contrary, the $\mathrm{Au} / \mathrm{TiO}_{2}$ reference catalyst gave an almost complete conversion after $180 \mathrm{~min}$ of reaction. Moreover, the selectivity was about $80 \%$ after $30 \mathrm{~min}$ and smoothly decreased to $65 \%$ at increasing reaction time. The decrease in selectivity was explained by performing FTIR measurements of adsorbed $\mathrm{CO}$ on the $\mathrm{Au} / \mathrm{TiO}_{2}$ samples before and after the inlet of methyl-2-furoate at room temperature. It was pointed out that methyl-2-furoate mainly interacts with the surface of the catalyst through its carbonylic group [39]. This feature was confirmed by examining the spectra of the adsorbed molecule in the $\mathrm{C}=\mathrm{O}$ stretching region $\left(1800-1650 \mathrm{~cm}^{-1}\right.$ range): in such range the spectra appeared more perturbed if compared to the finger print region $\left(1650-1000 \mathrm{~cm}^{-1}\right)$. Indeed, a variety of bands was observed, indicating the occurrence of different interactions involving several geometries of methyl-2-furoate and possibly different kinds of sites exposed at the surface of $\mathrm{Au} / \mathrm{TiO}_{2}$. In addition, methyl-2-furoate seemed to interact less strongly with the surface of the catalyst than what furfural did, basing on the intensity and on the stability of the bands observed in the $\mathrm{C}=\mathrm{O}$ stretching region [39].

The FTIR difference spectra collected upon $\mathrm{CO}$ adsorption on the activated catalyst (previously submitted to oxidation at $400{ }^{\circ} \mathrm{C}$ and reduction at $250{ }^{\circ} \mathrm{C}$, grey curve), on the catalyst simply outgassed at room temperature (orange curve), outgassed at $120^{\circ} \mathrm{C}$ (that is the reaction temperature, purple curve) and treated in oxygen atmosphere at $250{ }^{\circ} \mathrm{C}$ for $2 \mathrm{~h}$ (red curve) after interaction with methyl-2-furoate (5 mbar) are shown in Figure 4 in the carbonylic region.

Bands at 2204 and $2186 \mathrm{~cm}^{-1}$, assigned to $\mathrm{CO}$ on $\mathrm{Ti}^{4+}$ sites with different coordinative unsaturation [76] were detected on activated $\mathrm{Au} / \mathrm{TiO}_{2}$ (grey curve). Moreover, a sharp band at $2111 \mathrm{~cm}^{-1}$, typical of $\mathrm{CO}$ adsorbed on $\mathrm{Au}^{0}$ sites exposed at the surface of the nanoparticles, was also detected. 


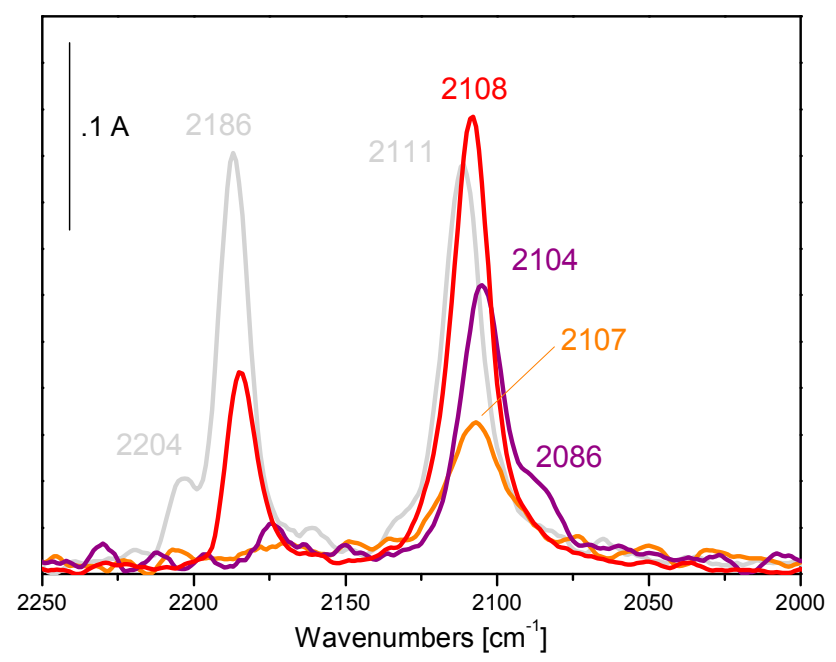

Figure 4. FTIR difference spectra collected upon the inlet of 15 mbar $\mathrm{CO}$ on activated $\mathrm{Au} / \mathrm{TiO}_{2}$ (deg. $200{ }^{\circ} \mathrm{C} /$ ox. at $400{ }^{\circ} \mathrm{C}$ in $\mathrm{O}_{2}$ and red./deg. at $250{ }^{\circ} \mathrm{C}$ in $\mathrm{H}_{2}$, grey curve), and on the catalyst simply outgassed at room temperature (orange curve), outgassed at $120^{\circ} \mathrm{C}$ (that is the reaction temperature, purple curve) and treated in oxygen atmosphere at $250{ }^{\circ} \mathrm{C}$ for $2 \mathrm{~h}$ (red curve) after interaction with methyl-2-furoate (5 mbar).

The outgassing at room temperature (orange curve) and at $120{ }^{\circ} \mathrm{C}$ (purple curve) partially recovered the Au sites, however it is necessary to submit the catalyst to prolonged treatment in oxygen atmosphere at $250{ }^{\circ} \mathrm{C}$ to restore totally the metal sites (band at $2108 \mathrm{~cm}^{-1}$ ) and only partially the $\mathrm{Ti}^{4+}$ support sites (band at $2186 \mathrm{~cm}^{-1}$ ) after interaction with methyl-2-furoate. Such spectroscopic findings indicated that methyl-2-furoate adsorbs on the uncoordinated gold sites exposed at the surface of the nanoparticles (according to the decrease in intensity of the CO band after contact with the molecule). Moreover, these gold sites are also modified by methyl-2-furoate, according to the changes in shape and position of the $\mathrm{CO}$ band after interaction with the molecule. Therefore, it can be supposed that a perturbation induced by methyl-2-furoate in terms of steric hindrance can decrease the strength of the $\mathrm{CO}$ bond, hence the differences in position and shape of the carbonylic band can be explained.

The spectroscopic findings put in evidence that the reaction product is almost irreversibly adsorbed on the $\mathrm{TiO}_{2}$ support and can give an explanation for the decrease in selectivity displayed by the $\mathrm{Au} / \mathrm{TiO}_{2}$ reference catalyst at increasing reaction times.

In addition, differently from what observed for $\mathrm{Au} / \mathrm{ZrO}_{2}$, where both furfural and methyl-2-furoate solely interact with the support and the gold uncoordinated sites are free to adsorb $\mathrm{CO}$, no $\mathrm{CO}$ adsorption occurred on $\mathrm{Au} / \mathrm{TiO}_{2}$ after reaction and subsequent outgassing at room temperature, or after thermal treatment in methanol at $150^{\circ} \mathrm{C}$. These results point out that on $\mathrm{Au} / \mathrm{TiO}_{2}$ all surface sites, i.e., metal and support sites, are covered by organic residuals and they are no more available to the $\mathrm{CO}$ probe after reaction. It is proposed that the different behavior observed upon $\mathrm{CO}$ adsorption can due to the different affinity of each support towards these molecules. Moreover, the different gold particles size distributions obtained for the two catalysts (see Table 2) can possibly have a role, too.

In summary, the different capability to interact with furfural and methyl-2-furoate and the different gold dispersion could explain the contrasting catalytic performances displayed by the two catalysts in the furfural esterification reaction to methyl-2-furoate. The different affinity towards furfural and methyl-2-furoate can be reasonably ascribed to the different acid/base properties of the two supports. Zirconia can be considered more acidic than titania, therefore the results put in evidence that the choice of a support containing Lewis acid sites can be appropriate for obtaining active catalyst, in agreement with a previous comparative study of the catalytic performance in the oxidation and esterification 
of 5-hydroxymethyl-2-furfural displayed by $\mathrm{Au} / \mathrm{CeO}_{2}$ with that related to $\mathrm{Au}$ nanoparticles onto different supports [28].

\subsection{Which Could Be the Best Choice of the Support?}

A comparative study on gold catalysts supported on various oxides was carried out recently by performing the furfural oxidative esterification to methyl-2-furoate in efficient and sustainable reaction conditions [77]. Therefore, different oxidic supports that are commonly used in catalysis were employed and investigated. In particular, plain $\mathrm{ZrO}_{2}, \mathrm{CeO}_{2}$, and $\mathrm{TiO}_{2}$ were examined.

$\mathrm{ZrO}_{2}$ is usually employed as a support due to its chemical and physical properties that can be opportunely modulated by the choice of different precursors and by varying the synthesis conditions [78]. $\mathrm{CeO}_{2}$ displays high oxygen storage capacity and reducibility [79]: we can take advantage of these properties in the furfural esterification reaction, in which atomic oxygen produced on gold species play a fundamental role. Finally, $\mathrm{TiO}_{2}$ is extensively employed in a variety of applications, because of its photocatalytic activity, non-toxicity, availability, low cost and stability. The physicochemical properties of $\mathrm{TiO}_{2}$, such as surface area, crystal structure (anatase, rutile, brookite), crystallite size and surface hydroxyl groups, have a deep influence on the catalytic behaviour [80].

In Table 4, the physicochemical properties of the samples are summarized along with the catalytic performances.

Table 4. Physicochemical properties and catalytic performances of the samples.

\begin{tabular}{cccccc}
\hline Catalyst & $\mathbf{A u}$ Loading (wt \%) & $\mathbf{m o l}_{\mathbf{C O}} / \mathbf{m o l}_{\mathbf{A u}}$ & Surface Area $\left(\mathbf{m}^{2} \mathbf{g}\right)$ & Conversion (\%) & Selectivity $(\%)$ \\
\hline $\mathrm{Au} / \mathrm{ZrO}_{2}$ & 1.0 & 0.24 & 39 & 82 & 92 \\
$\mathrm{Au} / \mathrm{CeO}_{2}$ & 2.2 & 0.06 & 105 & 66 & 69 \\
$\mathrm{Au} / \mathrm{TiO}_{2}$ & 1.2 & 0.004 & 166 & 20 & 91 \\
\hline
\end{tabular}

The $\mathrm{Au} / \mathrm{ZrO}_{2}$ catalyst showed very good catalytic performances for both conversion (82\%) and selectivity (92\%) [77]. As previously discussed, the catalytic activity of this sample is due to the very high dispersion of the gold phase, as indicated by $\mathrm{CO}$ chemisorption data. The $\mathrm{Au} / \mathrm{CeO}_{2}$ catalyst gave a conversion lower $(66 \%)$ than that related to the zirconia supported sample. The $\mathrm{mol}_{\mathrm{CO}} / \mathrm{mol}_{\mathrm{Au}}$ ratio obtained for this catalyst was 0.06 , indicating the presence of small gold nanoparticles [77]. However, selectivity dropped with respect to the $\mathrm{Au} / \mathrm{ZrO}_{2}$ catalyst, because 2-furaldehyde-dimethyl-acetal was remarkably produced on this sample. In contrast, the conversion for the $\mathrm{Au} / \mathrm{TiO}_{2}$ catalyst was very low $(20 \%)$, according to the presence of big gold particles with size around $4 \mathrm{~nm}$, even if the selectivity is surprisingly quite good and on a par with the value attained by $\mathrm{Au} / \mathrm{ZrO}_{2}$ sample (above $90 \%$ ). Therefore, the following trend in the catalytic activity was found: $\mathrm{Au} / \mathrm{ZrO} \mathrm{r}_{2}>\mathrm{Au} / \mathrm{CeO}_{2}>\mathrm{Au} / \mathrm{TiO}_{2}$. Again, these results quite clearly indicate that gold dispersion is a crucial factor controlling conversion. However, gold dispersion itself cannot explain the trend observed as for the selectivity. The effective gold content for each sample was in the range $1 \%-2 \%$ (Table 4 ).

Despite the lowest Au loading, if compared to the other catalysts, the zirconia supported sample gave the best catalytic results, indicating that the acid-base properties of the support strongly affected the activity, as confirmed by FTIR experiments of adsorption/desorption of $\mathrm{CO}_{2}$ at room temperature. The presence of suitably located free $\mathrm{OH}$ groups, which bring about the formation of hydrogen-carbonate species, is vital to lead to a good catalytic activity. This is achieved in the case of the zirconia-supported catalyst, for which a high gold dispersion was observed as well. The $\mathrm{Au} / \mathrm{CeO}_{2}$ system showed a quite good conversion, due to its good Au dispersion, but it exhibited low selectivity, due to the poor reactivity of its surface to give hydrogen-carbonate species. Finally, the low conversion value related to the $\mathrm{Au} / \mathrm{TiO}_{2}$ sample, which contains a quite good amount of $\mathrm{Ti}^{4+}-\mathrm{OH}$ species, that can explain its intrinsic good selectivity, was justified by the worst $\mathrm{Au}$ dispersion.

$\mathrm{Au}$ nanoparticles supported on a variety of metal oxides (such as $\mathrm{Al}_{2} \mathrm{O}_{3}, \mathrm{TiO}_{2}, \mathrm{MnO}_{2}, \mathrm{Fe}_{2} \mathrm{O}_{3}$, $\mathrm{Co}_{3} \mathrm{O}_{4}, \mathrm{NiO}, \mathrm{ZnO}, \mathrm{ZrO}_{2}$ and $\mathrm{CeO}_{2}$ ) were screened for the aerobic oxidation of 1-octanol in water 
and without adding a base [81]. It was found that the choice of basic metal oxides lead to superior catalytic activity if compared to that obtained for neutral or acidic oxides, because basic oxides favor the deprotonation of hydroxyl groups. Nevertheless, the basicity of the supports does not correlate with the activity order and octanoic acid was observed together with octyl octanoate as main product, in contrast with previous findings where the aldehyde is the main product in the absence of a base $[28,82]$. With the exception of $\mathrm{Au} / \mathrm{Co}_{3} \mathrm{O}_{4}$ that gave a $100 \%$ selectivity to octanal, a higher concentration of substrate was needed to obtain further octanal oxidation to octyl-octanoate by reaction with octanol. On the contrary, the highest selectivity to octyl octanoate was reached over $\mathrm{Au} / \mathrm{CeO}_{2}$ at low conversion, whereas $\mathrm{Au} / \mathrm{NiO}$ displayed the highest activity and selectivity to octanoic acid. Therefore, the selectivity can be tuned by opportunely choosing the nature of the support [82].

It was found that a cooperative effect between iron oxide and hydroxyapatite has a beneficial effect on the catalytic activity of $\mathrm{Au} / \mathrm{FH}$ catalysts (where $\mathrm{FH}$ refers to $\mathrm{Fe}_{\mathrm{x}} \mathrm{O}_{\mathrm{y}}$-hydroxyapatite) in the furfural transformation with aliphatic alcohols in the presence of oxygen [25]. It was found that furfural oxidative esterification occurred when methanol was employed, however the addition of a base was required to obtain high yield and selectivity.

Mesostructured Ga-Al mixed-oxide solid solutions have been proposed as highly promising supports for the fabrication of exceptionally effective gold catalysts for the aerobic alcohol oxidation under mild conditions [83]. Very high conversion and selectivity were obtained for several aromatic and aliphatic alcohols (such as for example benzyl alcohol and variously substituted benzyl alcohols) to the corresponding aldehyde or in some cases to the corresponding ketone under mild conditions $\left(90^{\circ} \mathrm{C}\right.$, under $\mathrm{O}_{2}$ at atmospheric pressure). Starting from benzyl alcohol, the maximum rate for the formation of benzaldehyde was observed for $\mathrm{Au} / \mathrm{Ga}_{3} \mathrm{Al}_{3} \mathrm{O}_{9}$ with molar ratio $\mathrm{Ga} / \mathrm{Al}=1: 1$, indicating that the specific nature of the solid solution affects the activity. Additional tests on bare $\mathrm{Ga}_{2} \mathrm{O}_{3}$ and $\mathrm{Al}_{2} \mathrm{O}_{3}$ supports revealed that the reaction occurred, but at much lower reaction rates. Furthermore, it was also shown that the catalysts were possibly capable of catalyzing alcohol dehydrogenation and that this capability was strongly dependent on the composition of the support. The maximum activity was achieved in the case of the $\mathrm{Ga}_{3} \mathrm{Al}_{3} \mathrm{O}_{9}$ solid solution containing $\mathrm{Ga} / \mathrm{Al}$ molar ratio of 1:1. It was also shown that $\mathrm{Au} / \mathrm{TiO}_{2}$ and $\mathrm{Au} / \mathrm{Fe}_{2} \mathrm{O}_{3}$ (provided by the World Gold Council) do not have alcohol dehydrogenation activity.

Finally, the comparison here reported among samples with very similar $\mathrm{mol}_{\mathrm{CO}} / \mathrm{mol}_{\mathrm{Au}} \mathrm{ratios}$ shown in Table 5 further confirms that the choice of the support is an essential step for improving the catalytic performances in the furfural oxidative esterification to methyl-2-furoate in the presence of oxygen and without any added base and to obtain structure activity relationships within the catalyst design.

Table 5. Physico-chemical properties of the samples and catalytic performances.

\begin{tabular}{ccccc}
\hline Catalyst & Conversion (\%) & Selectivity (\%) & mol $_{\mathbf{C O}} / \mathbf{m o l}_{\mathbf{A u}}$ & Reference \\
\hline $\mathrm{Au} / \mathrm{ZrO}_{2}$ calcined at $500{ }^{\circ} \mathrm{C}$ & 96 & 97 & 0.03 & {$[64]$} \\
$\mathrm{Au} / \mathrm{Ce}(\mathrm{OH})_{4}$ & 80 & 56 & 0.04 & [this review] \\
$\mathrm{Au} / \mathrm{TiO}_{2}$ WGC & 64 & 64 & 0.03 & {$[34]$} \\
\hline
\end{tabular}

It can be concluded that the zirconia supported sample displayed chemical and morphological properties, which contemporarily satisfy, on the one hand, the need for high gold dispersion to obtain high activity and, on the other hand, the need of the presence of non-acidic or -basic sites for good selectivity.

\section{Catalyst Design. Optimization of Gold Catalysts Supported on Ceria: A Case Study}

The collaborative effect between gold and cerium oxide has been elegantly demonstrated by Corma et al. [31]: indeed gold nanoparticles are able to transform nanocrystalline cerium oxide from a stoichiometric oxidant into a catalytic material for the selective oxidation of primary and 
secondary alcohols to aldehydes and ketones using oxygen at atmospheric pressure. High conversion and selectivity were obtained for a variety of substrates. It has been proposed that the surface of nanocrystalline ceria has a key role in improving the catalytic performances of $\mathrm{Au} / \mathrm{CeO}_{2}$ catalysts, due to the effective oxygen adsorption and activation on the oxygen vacancies formed during the redox process involving the $\mathrm{Ce}^{4+} / \mathrm{Ce}^{3+}$ pair [84]. Based on XANES, XPS and Ce EXAFS results, it was shown that the strong metal-support interaction involves a contact oxygen layer between the gold particle and the cerium oxide, giving rise to stable $\mathrm{Au}-\mathrm{O}-\mathrm{Ce}$ bonds at the interface [85]. The authors also proposed that such strong interaction enhances the oxygen mobility at the surface by weakening the $\mathrm{Ce}-\mathrm{O}$ bond.

$\mathrm{Au} / \mathrm{CeO}_{2}(2.1 \mathrm{wt} \%)$ has proven to be an excellent catalyst for the aerobic oxidation of 5-hydroxymethyl-2-furfural into 2,5-dimethylfuroate without base [28]. In another study, $\mathrm{CeO}_{2}$ nanoparticles of $5 \mathrm{~nm}$, rod-like particles with size $9.9 \mathrm{~nm}$ and $63 \mathrm{~nm}$ cubic shaped particles were employed as support for gold nanoparticles in order to investigate the effect of cerium oxide nanostructure on the reaction between $\alpha, \beta$-unsaturated aldehyde and methanol [43]. Despite a different gold loading, no significant differences were observed in the Au particle size on the three different morphologies even if with quite different surface areas. Moreover, the population of Ce(III) was larger in the case of nanoparticles and rod-like particles if compared to the cubic shaped particles. However, the authors observed changes in the selectivity when using methacrolein instead of acrolein, mainly due to the influence of the methyl group in the substrate.

The synthetic parameters affecting the $\mathrm{Au} / \mathrm{CeO}_{2}$ catalytic performances in furfural oxidative esterification to methyl-2-furoate without base were deeply investigated to unravel how the support rules the gold dispersion and then the catalytic activity [86].

Cerium oxide was synthesized following the procedure reported previously [87] and finally simply dried at room temperature $\left(\mathrm{CeO}_{2} \mathrm{C} 90\right)$ and at $110{ }^{\circ} \mathrm{C}\left(\mathrm{CeO}_{2} \mathrm{C} 110\right)$. Based on TG/DTA results, the sample was calcined at $300{ }^{\circ} \mathrm{C}$ and at $500{ }^{\circ} \mathrm{C}$ to obtain supports completely or partially free from residual species at the surface during the decomposition the Ce precursor, which can behave as poison during the reaction. As shown in Figure 5, gold was then introduced by deposition-precipitation on the different ceria supports.

\begin{tabular}{|c|c|c|c|c|}
\hline \multirow{3}{*}{\multicolumn{2}{|c|}{ 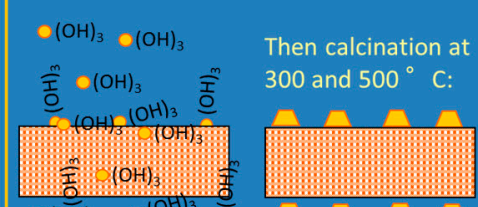 }} & Support & $\begin{array}{c}\text { Calcination } \\
\text { temperature }\left({ }^{\circ} \mathrm{C}\right)\end{array}$ & Catalyst \\
\hline & & $\mathrm{CeO}_{2} \mathrm{CgO}$ & 300 & $\mathrm{Au} / \mathrm{CeO}_{2} \mathrm{CgOC} 0 \mathrm{O}$ \\
\hline & & $\mathrm{CeO}_{2} \mathrm{CgO}$ & 500 & $\mathrm{Au} / \mathrm{CeO}_{2} \mathrm{C}_{90 \mathrm{C} 500}$ \\
\hline 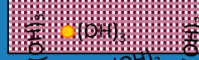 & & $\mathrm{CeO}_{2} \mathrm{C} 110$ & 300 & $\mathrm{Au} / \mathrm{CeO}_{2} \mathrm{Cl10C300}$ \\
\hline (10H) & & $\mathrm{CeO}_{2} \mathrm{Cl10}$ & 500 & $\mathrm{Au} / \mathrm{CeO}_{2} \mathrm{Cl10C500}$ \\
\hline & & $\mathrm{CeO}_{2} \mathrm{C} 30 \mathrm{O}$ & 300 & $\mathrm{Au} / \mathrm{CeO}_{2} \mathrm{C} 300 \mathrm{C} 300$ \\
\hline 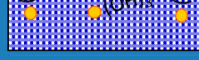 & & $\mathrm{CeO}_{2} \mathrm{C} 500$ & 500 & $\mathrm{Au} / \mathrm{CeO}_{2} \mathrm{C500C500}$ \\
\hline
\end{tabular}

Figure 5. (A) Gold deposition-precipitation on the different $\mathrm{CeO}_{2}$ supports; and (B) list of the obtained catalysts after subsequent calcination at $400{ }^{\circ} \mathrm{C}$ and $500{ }^{\circ} \mathrm{C}$.

It is worth noting that, with the exception of Ce90, XRD measurements performed on the supports calcined at different temperature confirm that both structure and size of the obtained ceria did not change either by increasing the temperature up to $500{ }^{\circ} \mathrm{C}$ or by introducing gold and performing the second calcination at $300^{\circ} \mathrm{C}$ and $500^{\circ} \mathrm{C}$.

In Table 6, the effective gold content of the catalysts prepared by deposition precipitation is reported. Such content is quite similar to the nominal one when considering the samples supported on $\mathrm{CeO}_{2} \mathrm{C} 110, \mathrm{CeO}_{2} \mathrm{C} 300$ and $\mathrm{CeO}_{2} \mathrm{C} 500$, whereas on the two catalysts supported on $\mathrm{CeO}_{2} \mathrm{C} 90$ the 
gold amount is higher than the nominal content because of the presence of water on the support as a consequence of the drying performed at room temperature. The selectivity to methyl-2-furoate is $100 \%$ for all the samples, in agreement with previous spectroscopic findings, which revealed that its formation occurred without generation of any adsorbed intermediate species and that the reaction proceeded by direct furfural selective oxidation to the desired furoate [39].

Table 6. Properties of the samples and catalytic activity after 90 min reaction.

\begin{tabular}{cccccc}
\hline Catalyst & $\begin{array}{c}\text { Au Nominal } \\
\text { Content (wt \%) }\end{array}$ & $\begin{array}{c}\text { Au Effective } \\
\text { Content } \mathbf{( w t ~ \% )}\end{array}$ & $\begin{array}{c}\text { Surface Area } \\
\left(\mathbf{m}^{\mathbf{2}} \mathbf{g}\right)\end{array}$ & $\begin{array}{c}\text { Conversion } \\
(\mathbf{\%})\end{array}$ & $\begin{array}{c}\text { Selectivity } \\
\mathbf{( \% )}\end{array}$ \\
\hline $\mathrm{Au} / \mathrm{CeO}_{2} \mathrm{C} 90 \mathrm{C} 300$ & 1.5 & 2.1 & 180 & 29 & 100 \\
$\mathrm{Au} / \mathrm{CeO}_{2} \mathrm{C} 90 \mathrm{C} 500$ & 1.5 & 2.1 & 105 & 6 & 100 \\
$\mathrm{Au} / \mathrm{CeO}_{2} \mathrm{C} 110 \mathrm{C} 300$ & 1.5 & 1.3 & 121 & 29 & 100 \\
$\mathrm{Au} / \mathrm{CeO}_{2} \mathrm{C} 110 \mathrm{C} 500$ & 1.5 & 1.3 & 121 & 28 & 100 \\
$\mathrm{Au} / \mathrm{CeO}_{2} \mathrm{C} 300 \mathrm{C} 300$ & 1.5 & 1.4 & 124 & 54 & 100 \\
$\mathrm{Au} / \mathrm{CeO}_{2} \mathrm{C} 500 \mathrm{C} 500$ & 1.5 & 1.5 & 110 & 74 & 100 \\
\hline
\end{tabular}

The conversion values listed in Table 6 clearly indicate that the calcination of the support is a key step in the synthetic procedure for obtaining active catalysts. In particular, the higher is the calcination temperature of the support, the higher is the catalytic activity. This is valid for the two series of samples re-calcined at $300{ }^{\circ} \mathrm{C}$ or $500{ }^{\circ} \mathrm{C}$ after gold introduction. Moreover, the two catalysts supported on $\mathrm{CeO}_{2} \mathrm{C} 90$ show very low conversion. These observations make the $\mathrm{CeO}_{2} \mathrm{C} 90$ support not suitable for the preparation of active gold catalysts, further confirming that crystalline $\mathrm{CeO}_{2}$ nanoparticles are needed. According to Table 6, the best performing catalyst is the one supported on $\mathrm{CeO}_{2} \mathrm{C} 500$ submitted to final calcination at $500{ }^{\circ} \mathrm{C}$ after gold deposition-precipitation. The following trend was obtained: Ce500Au500 > Ce300Au300 > Ce110Au500 Ce110Au300 Ce90Au300 > Ce90Au500.

Unexpectedly, based on the above results corroborated by CO chemisorption, HRTEM and diffuse reflectance UV-Vis analyses, it was demonstrated that differently from what observed for $\mathrm{Au} / \mathrm{ZrO}_{2}$ catalysts, the $\mathrm{Au} / \mathrm{CeO}_{2}$ catalysts need no gold cluster to activate oxygen and to catalyze the reaction (Figure 6). No influence on the selectivity to methyl-2-furoate has been observed.

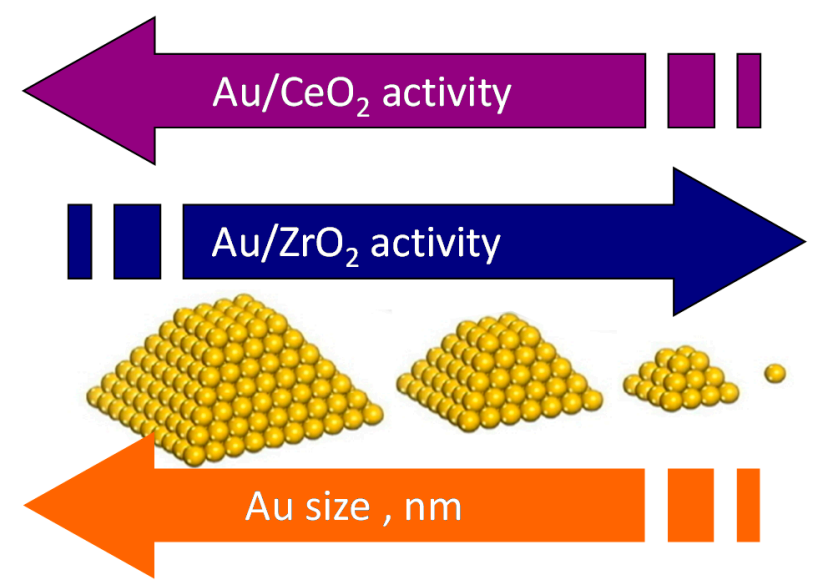

Figure 6. Dependence of the catalytic activity of $\mathrm{Au} / \mathrm{CeO}_{2}$ and $\mathrm{Au} / \mathrm{ZrO}_{2}$ catalysts on the $\mathrm{Au}$ size.

In addition, the characterization by FTIR spectroscopy showed that different amounts of carbonate species are present at the surface of $\mathrm{Au} / \mathrm{CeO}_{2} \mathrm{C} 300 \mathrm{C} 300$ and $\mathrm{Au} / \mathrm{CeO}_{2} \mathrm{C} 500 \mathrm{C} 500$. The abundance of these species as well as the exclusive presence of more coordinated $\mathrm{Ce}^{4+}$ sites on $\mathrm{Au} / \mathrm{CeO}_{2} \mathrm{C} 500 \mathrm{C} 500$ can explain the different catalytic activity displayed by the two systems, being related to the capability of ceria to provide activated oxygen with consequent formation of oxygen vacancies. The cleaner is the ceria surface, the higher is the ability to release oxygen. 
It has been proposed that reverse oxygen spillover occurs at the perimeter of the nanoparticles, according to Scheme 6A and that such gold perimeter sites can activate methanol molecules (Scheme 6B). $\mathrm{Au} / \mathrm{CeO}_{2} \mathrm{C} 500 \mathrm{C} 500$ was contacted with methanol and furfural at $120^{\circ} \mathrm{C}$ for $30 \mathrm{~min}$ in the absence of $\mathrm{O}_{2}$ in order to force the oxygen atoms coming from ceria to take part to the reaction as well as to be able to distinguish between oxygen coming from ceria and oxygen coming from the gas phase. Some weak bands related to the presence of methyl-2-furoate are detected after heating in the methanol/furfural mixture at $120^{\circ} \mathrm{C}$ for $30 \mathrm{~min}$ and cooling at room temperature [39]. Moreover, the band at $1106 \mathrm{~cm}^{-1}$ due to on top methoxy species [88,89] and formed upon methanol inlet at room temperature markedly decreased in intensity after heating in the reaction mixture at $120^{\circ} \mathrm{C}$ for $30 \mathrm{~min}$, confirming the involvement of methoxy species.

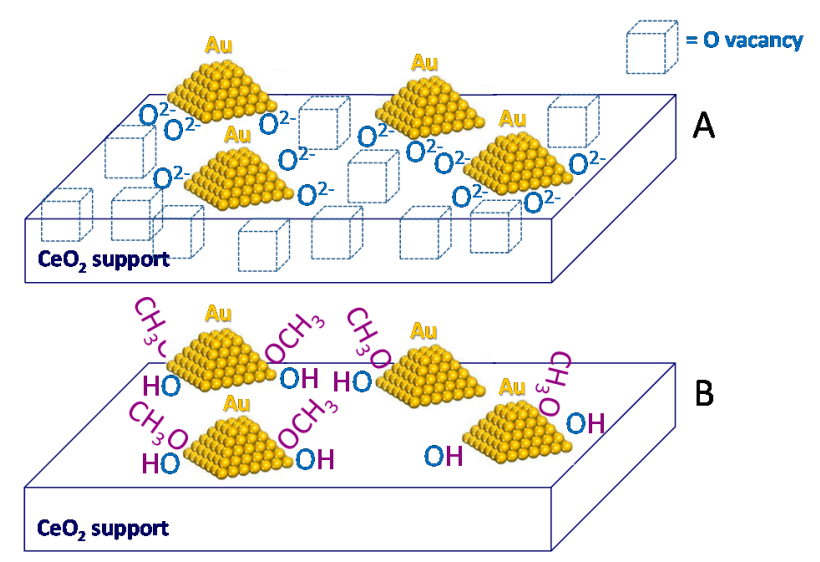

Scheme 6. (A) Reverse oxygen spillover from the ceria surface of $\mathrm{Au} / \mathrm{CeO}_{2} \mathrm{C} 500 \mathrm{C} 500$ to the perimeter of gold nanoparticles where methanol is activated (B).

Furthermore, $\mathrm{CO}$ adsorption at $-180{ }^{\circ} \mathrm{C}$ was performed to monitor the surface of the catalyst before and after the inlet of the methanol/furfural mixture to probe the nature of the exposed sites (data not shown). The presence of a very intense absorption band with maximum at $2156 \mathrm{~cm}^{-1}$ due to $\mathrm{CO}$ on $\mathrm{Ce}^{4+}$ sites [90] and of a band at $2101 \mathrm{~cm}^{-1}$, due to $\mathrm{CO}$ on gold sites [91,92] was observed on the catalyst surface before reaction. A band at $2147 \mathrm{~cm}^{-1}$, due to $\mathrm{CO}$ on $\mathrm{Ce}^{3+}$ sites [92] and a very weak absorption at $2100 \mathrm{~cm}^{-1}$, related to $\mathrm{CO}$ on gold, are observed after contacting the $\mathrm{Au} / \mathrm{CeO}_{2} \mathrm{C} 500 \mathrm{C} 500$ with methanol and furfural at $120^{\circ} \mathrm{C}$ for $30 \mathrm{~min}$. Moreover, a broad adsorption at $2135 \mathrm{~cm}^{-1}$, assigned to $\mathrm{CO}$ on positively charged gold [93], was still detected upon outgassing at low temperature. A band at $2340 \mathrm{~cm}^{-1}$ related to the asymmetric stretching of $\mathrm{CO}_{2}$ molecularly adsorbed [50] was also observed upon $\mathrm{CO}$ inlet, indicating that some residual oxygen adsorbed on gold reacted with the probe.

The above findings indicate the occurrence of the oxygen reverse spillover: indeed, the ceria surface is reduced, as indicated by the band related to $\mathrm{Ce}^{3+}$ sites, and gold is partially oxidized, in agreement with the possibility of reverse spill over. Therefore, the oxygen reverse spillover could make the gold sites located at the perimeter of the Au nanoparticles close to the ceria support able to activate effectively the methanol molecule, similarly to what previously observed [34,64].

Finally, the adsorbed methoxy species observed after inlet of methanol at room temperature were less stable on the surface of $\mathrm{Au} / \mathrm{CeO}_{2} \mathrm{C} 500 \mathrm{C} 500$, further indicating an enhanced reactivity on this sample [86].

It is worth noting that gold catalysts prepared by sol-gel and supported on $\mathrm{CeO}_{2}-\mathrm{Al}_{2} \mathrm{O}_{3}$ mixed oxides are more active than $\mathrm{Au}$ on $\mathrm{CeO}_{2}$ or $\mathrm{Al}_{2} \mathrm{O}_{3}$ in the base-free benzaldehyde oxidative esterification in benzyl alcohol, despite the lower Au content [94]. Interestingly, the most active systems are those possessing surface Lewis acid sites with weak and medium strength. Methyl benzoate was the main product and the product distribution was similar for both series of catalysts, i.e., oxidized or reduced. Moreover, the activity was superior for the catalysts submitted to the thermal pretreatment in oxygen. 
The authors ascribed the pronounced synergetic effect between $\mathrm{CeO}_{2}$ and $\mathrm{Al}_{2} \mathrm{O}_{3}$ to the improved oxygen storage capacity of the mixed oxides with respect to pure ceria and pure alumina. Moreover, it was demonstrated that the insertion of ceria into alumina can favor the oxygen activation by gold nanoparticles further improving their reactivity in the oxidation.

\section{Stability of the Gold Species under Reaction Conditions}

The catalyst stability can be considered either as a technical or as an economic parameter affecting the overall process [95]. The influence of catalyst deactivation on the performance of a given type of reactor or on the economics of the process has been the subject of a number of quantitative analyses [96,97]. Moreover, catalyst deactivation may affect the process design in the selection of process options, such as configuration and reactor type; additionally, the operation of an industrial process can be influenced or even dictated by the deactivation of the catalyst [95].

The nature of catalyst deactivation, the possibility to recover the lost activity either during the operation of the process or in a separate regeneration step as well as the deactivation rate are factors ruling such process options. Therefore, catalyst deactivation has important consequences for the design of a process and the way it is operated.

The loss of activity during a process can be ascribed to many factors: (i) poisoning of the active sites or (ii) impurities in the feed or by-products can inhibit the reaction; (iii) polymeric material, including coke, can be produced as a result of side or consecutive reactions and deposit on the surface; and (iv) occurrence of sintering of the small particles causing loss of metal dispersion and of activity. Moreover, deactivation can occur (v) by leaching, due to the fact that metal leaching cannot be ruled out for a reaction working in solvent medium for many hours; or (vi) by changes in the catalyst porous texture [64].

Generally, gold heterogeneous catalysts have been reported to be significantly active and selective in a variety of reactions in both the liquid and gas phases, however they suffer of irreversible activation. As a consequence, it is particularly important to find and optimize procedures by which gold catalysts can be stabilized or reactivated. The use of methyl iodide as a method for redispersing gold nanoparticles on different oxidic supports has been reported [98]. It was found that the extent of redispersion was deeply influenced by the nature of the oxide employed as support. As for $\mathrm{TiO}_{2}$ - and $\mathrm{Al}_{2} \mathrm{O}_{3}$-base catalysts, the gold nanoparticles were transformed into small clusters and atomically dispersed $\mathrm{Au}$. On the contrary, $\mathrm{SiO}_{2}$-supported systems were weakly modified by the treatment with $\mathrm{CH}_{3} \mathrm{I}$. Indeed, in this case the gold size remained in the submicrometer range. The structural changes induced by $\mathrm{CH}_{3} \mathrm{I}$ were correlated with those observed as for the activity and selectivity in ethanol dehydration and benzyl alcohol oxidation. In situ aberration-corrected electron microscopy was used to investigate the stability of expansive surface strain and low coordination surface atoms of gold nanoparticles as a function of temperature [99]. It was proposed that the minimization of the surface energy leads to the disappearance of the under coordinate surface atoms and to the formation of atomically clean facets, explaining the initial drop in activity of the catalysts. Moreover, the expansive surface strain resulting from inherently strained decahedral structures decreases when the particle size increases. At elevated temperature, the lower surface energy anisotropy can give rise to energetically favorable morphologies with minimized strain. Interestingly, these processes act as structural deactivation mechanism because of the loss of active sites without any necessary associated decrease in surface area or change in particle size by traditional sintering mechanisms.

As for the procedures employed to regain the activity of the gold catalysts after use, it was reported that polymer incarcerated gold catalysts successfully employed for the aerobic oxidative esterification of alcohols can be recovered by simple filtration and washing with water and methanol [70]. The catalyst could be reused four times without significant loss of activity. Moreover, the catalysts with decreased activity after repeated use were restored by heating at $170^{\circ} \mathrm{C}$ for $4 \mathrm{~h}$. Gold nanoparticles supported on salts of polyoxometalates are highly active ( $>90 \%$ conversion) selective to epoxide formation for norbornene and cyclooctene oxidation and recyclable catalysts for the epoxidation of 
olefins using molecular oxygen as oxidant and t-butyl hydroperoxide as initiator [100]. Such catalyst showed little deactivation with prolonged reaction time and was easily recovered by filtration and was reused with almost no loss in activity and selectivity. In conclusion, it was shown that the use of anionic polyoxometalate support material for gold gave very stable materials.

The reusability of Au supported on ceria was investigated in the 5-hydroxymethyl-2-furfural conversion into 2,5-dimethylfuroate by performing a sequence of cycles under the same reaction conditions [28]. The catalyst was recovered by simple vacuum filtration and subsequent washing with methanol and drying overnight. The time required to reach similar yield than the fresh catalyst was nearly twice and the initial conversion rate was almost halved. The authors proposed that such behavior could be due to the presence of $11 \mathrm{wt} \%$ organic material after the first cycle. The amount of organic material increased when going on with the cycles and it was not removed by extraction with methanol. Therefore, a calcination in air at $250{ }^{\circ} \mathrm{C}$ for $12 \mathrm{~h}$ was performed to partially remove the organic material $(<5 \%$ organic still present on the catalyst) and the activity was almost totally restored.

The stability the $\mathrm{Au} / \mathrm{ZrO}_{2}$ catalysts described in Section 3 was also investigated [64,101]. The attention was focused on the stability and on the possibility to reuse the most active $\mathrm{Au} / \mathrm{ZrO}_{2}$ sample calcined at $500{ }^{\circ} \mathrm{C}$. In order to investigate this point, some experiments were carried out in the presence of the sample previously undergone to a first catalytic run: the solid was filtered off, washed with methanol and dried at $110^{\circ} \mathrm{C}$ overnight. Different from what was previously observed [28], such procedure was not adequate to recover the initial performances; indeed, the selectivity was particularly low and it collapsed from 98\% to 29\% (as shown in Figure 7).

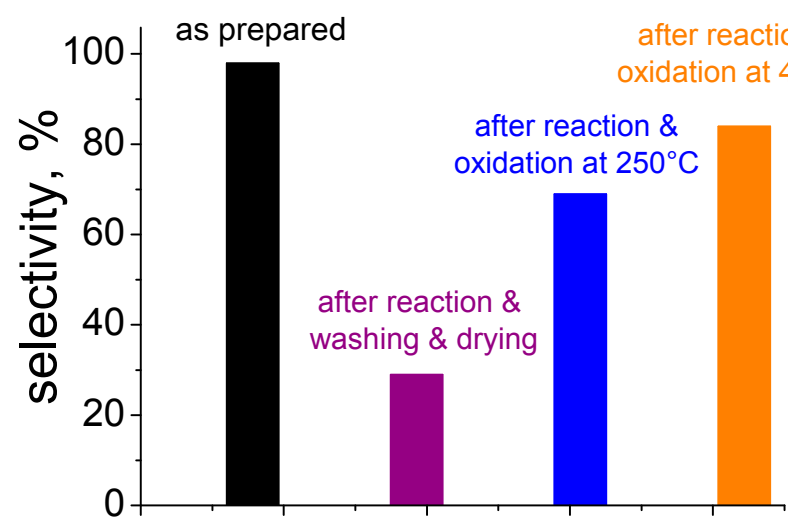

Figure 7. Comparison among the selectivity of the as prepared sample and after different reactivation procedures.

Chemical analysis by atomic absorption of gold was carried out on the exhausted catalysts, i.e., the samples examined after $3 \mathrm{~h}$ of reaction in methanol and stirred at $1000 \mathrm{rpm}$. The Au content was the same obtained for the as prepared samples ( $1.5 \mathrm{wt} \%$ vs. $1.5 \mathrm{wt} \%)$. The selectivity decrease shown by the $\mathrm{Au} / \mathrm{ZrO}_{2}$ catalysts could be also ascribed to the sintering of gold clusters during 2-FA esterification reaction [64]. However, the mean Au particle size was unchanged after the catalytic test ( $2.8 \mathrm{~nm}$ vs. $2.7 \mathrm{~nm}$ ) as revealed by HRTEM. As a consequence, gold sintering problems throughout the reaction time have been ruled out; also considering that the reaction was performed at $120^{\circ} \mathrm{C}$, well below the temperature at which the calcination was performed $\left(500^{\circ} \mathrm{C}\right)$.

In order to investigate fouling of the active sites and to check the eventual presence of any carbon-based residue, temperature programmed oxidation (TPO) measurements were performed $[64,98]$. The evolution of $\mathrm{CO}_{2}$ was proved by the presence of a broad band in the TPO curve related to the $\mathrm{Au} / \mathrm{ZrO}_{2}$ sample calcined at $500{ }^{\circ} \mathrm{C}$ after reaction. It was found that the catalyst needed to be reactivated by a thermal treatment in $\mathrm{O}_{2}$ up to $450{ }^{\circ} \mathrm{C}$ to obtain the complete removal of the residual carbonaceous species, to re-establish the full conversion and to recover almost completely the selectivity [34,98]. 
An appropriate choice of the temperature of oxidation, to which the exhausted catalyst is submitted, allows the almost complete recovery of the catalytic performances. The FTIR spectra of adsorbed $\mathrm{CO}$ on $\mathrm{Au} / \mathrm{ZrO}_{2}$ calcined at $500^{\circ} \mathrm{C}$ submitted to reactivation in $\mathrm{O}_{2}$ at increasing temperature (Figure 8, red curve) demonstrate that the oxidation at a proper temperature permits to remove the organic residue from either gold active sites or zirconia.

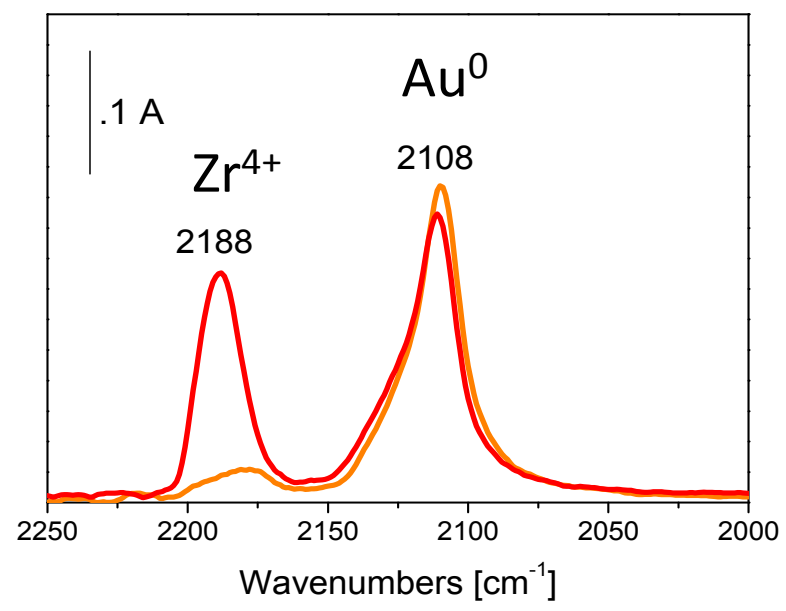

Figure 8. FTIR difference spectra collected upon the inlet of $15 \mathrm{mbar} \mathrm{CO}$ at room temperature on $\mathrm{Au} / \mathrm{ZrO}_{2}$ calcined at $500{ }^{\circ} \mathrm{C}$ after reactivation in $\mathrm{O}_{2}$ at $250{ }^{\circ} \mathrm{C}$ (orange curve) and at $450{ }^{\circ} \mathrm{C}$ (red curve).

Indeed, if the reactivation in oxygen atmosphere is performed at $250{ }^{\circ} \mathrm{C}$ only the band at $2018 \mathrm{~cm}^{-1}$, due to CO adsorbed on Au sites is observed (orange curve).

It is worth noting that the Au active phase displays quite high stability, even after repeated activations in $\mathrm{O}_{2}$ at increasing temperature.

As a result, it has been demonstrated that the catalytic activity can be entirely recovered when the organic residue of the exhausted sample is removed from both gold and zirconia sites. Such findings suggested that the support is not a simple spectator, but it also plays a role in the furfural esterification reaction to methyl-2-furoate.

Au supported on ceria-alumina mixed oxides was proved to be a very efficient and highly stable catalyst for the aerobic oxidative esterification of benzyl alcohol and acetaldehyde [94]. The Au catalyst supported on a mixed oxide containing $30 \mathrm{wt} \% \mathrm{CeO}_{2}$ was reused after a first catalytic run to convert another amount of substrate without significant loss of activity and selectivity. Inductively coupled plasma analysis showed no Ce in the solution separated from the catalyst after reaction and very small concentrations of $\mathrm{Al}$ and $\mathrm{Au}(0.05 \%$ and $0.12 \%$ loss, respectively). To further verify the eventual catalyst loss, fresh benzyl alcohol was added to the recovered supernatant and the solution was placed in the autoclave under oxidation conditions $\left(110^{\circ} \mathrm{C}, 10 \mathrm{~atm}\right.$ of $\left.\mathrm{O}_{2}\right)$. No further conversion was observed, indicating the lack of significant $\mathrm{Au}$ leaching to the liquid phase during the process and showed that the reaction was truly heterogeneous. Indeed, the catalysts, which are solid materials insoluble in the reaction mixture, were separated from the products by simple centrifugation or filtration, representing an important technological advantage of the process.

Several noble metal catalysts were tested in the direct oxidation of alcohol ethoxylates into alkyl ether carboxylic acids using $\mathrm{H}_{2} \mathrm{O}_{2}$ as an oxidant in the presence of $\mathrm{NaOH}$ [102]. Among the different catalysts, $\mathrm{Au} / \mathrm{TiO}_{2}$ and $\mathrm{Au} / \mathrm{Al}_{2} \mathrm{O}_{3}$ displayed high yield (up to $88 \%$ ) to plyoxyethylene(7) lauryl ether carboxylic acid at $80^{\circ} \mathrm{C}$. Several factors, such as the catalyst loading, the effect of the gold size, of the reaction time and temperature as well as the influence of the base amount were investigated, it was also found that $\mathrm{Au} / \mathrm{TiO}_{2}$ and $\mathrm{Au} / \mathrm{Al}_{2} \mathrm{O}_{3}$ could only be reused for two consecutive runs, because they underwent to strong deactivation during the third cycle. ICP-AES analysis and TEM measurements put in evidence the occurrence of $\mathrm{Au}$ leaching and partial nanoparticle sintering. The authors showed that 
the $\mathrm{Au}$ stability can be highly increased by adopting the strategy of incorporating $\mathrm{Pt}$ to the $\mathrm{Au} / \mathrm{TiO}_{2}$ catalyst. The bimetallic AuPt/ $\mathrm{TiO}_{2}$ catalyst showed a good recyclability and was reused for at least ten consecutive runs.

\section{Conclusions and Future Perspectives}

Within the exploitation of renewable raw materials such as lignocellulosic biomass, the use of heterogeneous catalysis is permitting the advancement of a new chemistry with enormous potential, because it can develop processes and products that are more sustainable from both environmental and economic points of view. The development of environmentally benign and cost-effective procedures for the synthesis of esters is attracting much interest. Supported gold nanoparticles can have a key role in the field of environmental catalysis in which new pathways for obtaining bio-derived molecules can be investigated. Indeed, a great number of novel gold-based catalysts have been reported in recent years for the green and selective oxidation of oxygen containing molecules in the presence of molecular oxygen as benign oxidant. A closer inspection of the described catalysts reveals that it is important not only to control the Au particle size, but also to focus on the nature of the support as well as on the synthetic parameters to control the morphology and the electronic properties of the obtained material. In the majority of the examined catalysts, the synthesis of gold nanoparticles with size ranging from 2 up to 5-6 nm appears to be the best choice to obtain high catalytic activity. However, many of these systems are working with a base as co-catalyst and several studies on the effect of the nature of the base have been performed. It has been shown that good performances on the 2-FA oxidative esterification to methyl-2-furoate can be obtained even avoiding the use of a base, which would render the process less environmentally and economically sustainable.

The described results represent a valuable starting point to new green base-free processes for the production of value-added esters in the presence of molecular oxygen and may also open the door for other high-value compounds such as for example carboxylic acids. Furthermore, a significant improvement would be the use of heterogeneous catalysts that allow the isolation of product(s) by simple separation. In the future, the catalyst design will be strategic to improve atom and energy efficiency, especially for industrial applications. In this frame, more intense efforts are required in the area of scaling up supported gold-based catalysts. The deep comprehension of the reaction mechanism supported by extended characterization studies will help unravel the nature of the active sites leading to the design and synthesis of more performing and stable materials. Therefore, the main challenges that researchers have to undertake in the near future can be summarized into the following points: (i) investigate the formation and the role of the active sites; (ii) understand the role of the support in the catalytic lifetime; (iii) lower the Au content to obtain cheaper catalysts able to work without adding a base; and (iv) scale up the catalyst synthesis.

Acknowledgments: Financial support to this work by MIUR-Italy (Cofin. 2008) is gratefully acknowledged.

Author Contributions: Maela Manzoli, Federica Menegazzo and Michela Signoretto contributed to the overall discussion. The manuscript was written by Maela Manzoli. Damiano Marchese carried out the catalytic tests over the gold catalysts described in the papers by the research group.

Conflicts of Interest: The authors declare no conflict of interest. The founding sponsors had no role in the design of the study; in the collection, analyses, or interpretation of data; in the writing of the manuscript, and in the decision to publish the results.

\section{References}

1. Perlack, R.D.; Wright, L.L.; Turhollow, A.; Graham, R.L.; Stokes, B.; Erbach, D.C. Biomass as Feedstock for a Bioenergy and Bioproducts Industry: The Technical Feasibility of a Billion-Ton Annual Supply; Oak Ridge Naional Laboratory, US Department of Energy: Oak Ridge, TN, USA, 2005.

2. Kudakasseril, K.J.; Raveendran, N.G.; Hussain, A.; Vijaya Raghavan, G.S. Feedstocks, logistics and pre-treatment processes for sustainable lignocellulosic bio-refineries: A comprehensive review. Renew. Sustain. Energy Rev. 2013, 25, 205-219. [CrossRef] 
3. Tekin, K.; Karagöz, S.; Bektaş, S. A review of hydrothermal biomass processing. Renew. Sustain. Energy Rev. 2014, 40, 673-687. [CrossRef]

4. Yan, K.; Jarvis, C.; Gu, J.; Yan, Y. Production and catalytic transformation of levulinic acid: A platform for speciality chemicals and fuels. Renew. Sustain. Energy Rev. 2015, 51, 986-997. [CrossRef]

5. Yan, K.; Yang, Y.; Chai, J.; Lu, Y. Catalytic reactions of gamma-valerolactone: A platform to fuels and value-added chemicals. Appl. Catal. B 2015, 179, 292-304. [CrossRef]

6. Yan, K.; Wu, G.; Lafleur, T.; Jarvis, C. Production, properties and catalytic hydrogenation of furfural to fuel additives and value-added chemicals. Renew. Sustain. Energy Rev. 2014, 38, 663-676. [CrossRef]

7. Climent, M.J.; Corma, A.; Iborra, S. Conversion of biomass platform molecules into fuel additives and liquid hydrocarbon fuels. Green Chem. 2014, 16, 516-547. [CrossRef]

8. Dutta, S.; De, S.; Saha, B.; Alam, M.I. Advances in conversion of hemicellulosic biomass to furfural and upgrading to biofuels. Catal. Sci. Technol. 2012, 2, 2025-2036. [CrossRef]

9. Ratanakhanokchai, K.; Waeonukul, R.; Pason, P.; Tachaapaikoon, C.; Kyu, K.L.; Sakka, K.; Kosugi, A.; Mori, Y. Paenibacillus Curdlanolyticus Strain B-6 Multienzyme Complex: A Novel System for Biomass Utilization; Matovic, M.D., Ed.; InTech: Rijeka, Croatia, 2013; ISBN: 978-953-51-1106-1. [CrossRef]

10. Lange, J.P. Lignocellulose conversion: An introduction to chemistry, process and economics. Biofuels Bioprod. Biorefin. 2007, 1, 39-48. [CrossRef]

11. Werpy, T.; Petersen, G.R. Results of Screening for Potential Candidates from Sugars and Synthesis Gas. Top Value Added Chemicals from Biomass; U.S. Department of Energy: Washington, DC, USA, 2004; Volume I. Available online: http://www.nrel.gov/docs/fy04osti/35523.pdf (accessed on 15 March 2016).

12. Bozell, J.J.; Petersen, G.R. Technology development for the production of biobased products from biorefinery carbohydrates-The US Department of Energy's “Top 10" revisited. Green Chem. 2010, 12, 539-554. [CrossRef]

13. Wu, C.; Chen, W.; Zhong, L.; Peng, X.; Sun, R.; Fang, J.; Zheng, S. Conversion of xylose into furfural using lignocellulosic acid as catalyst in ionic liquid. J. Agric. Food Chem. 2014, 62, 7430-7435. [CrossRef] [PubMed]

14. Kim, E.S.; Liu, S.; Abu-Omar, M.M.; Mosier, N.S. Selective conversion of biomass hemicellulose to furfural using maleic acid with microwave heating. Energy Fuels 2012, 26, 1298-1304. [CrossRef]

15. Lange, J.-P.; van der Heide, E.; van Buijtenen, J.; Price, R. Furfural-A promising platform for lignocellulosic biofuels. ChemSusChem 2012, 5, 150-166. [CrossRef] [PubMed]

16. Bohre, A.; Dutta, S.; Saha, B.; Abu-Omar, M.M. Upgrading furfurals to drop-in biofuels: An overview. ACS Sustain. Chem. Eng. 2015, 3, 1263-1277. [CrossRef]

17. Stevens, J.G.; Bourne, R.A.; Twigg, M.V.; Poliakoff, M. Real-time product switching using a twin catalyst system for the hydrogenation of furfural in supercritical $\mathrm{CO}_{2}$. Angew. Chem. Int. Ed. 2010, 49, 8856-8859. [CrossRef] [PubMed]

18. Fang, R.; Liu, H.; Luque, R.; Li, Y. Efficient and selective hydrogenation of biomass-derived furfural to cyclopentanone using Ru catalysts. Green Chem. 2015, 17, 4183-4188. [CrossRef]

19. Zhang, G.-S.; Zhu, M.-M.; Zhang, Q.; Liu, Y.-M.; He, H.-Y.; Cao, Y. Towards quantitative and scalable transformation of furfural to cyclopentanone with supported gold catalysts. Green Chem. 2016. [CrossRef]

20. Guo, H.; Yin, G. Catalytic aerobic oxidation of renewable furfural with phosphomolybdic acid catalyst: An alternative route to maleic acid. J. Phys. Chem. C 2011, 115, 17516-17522. [CrossRef]

21. Weingarten, R.; Cho, J.; Conner, C.; Huber, G.W. Kinetics of furfural production by dehydration of xylose in a biphasic reactor with microwave heating. Green Chem. 2010, 12, 1423-1429. [CrossRef]

22. Fernando, S.; Adhikari, S.; Chandrapal, C.; Murali, N. Biorefineries: Current status, challenges, and future direction. Energy Fuels 2006, 20, 1727-1737. [CrossRef]

23. Liu, Z.; Tong, X.; Liu, J.; Xue, S. A smart catalyst system for the valorization of renewable furfural in aliphatic alcohols. Catal. Sci. Technol. 2016, 6, 1214-1221. [CrossRef]

24. Mallat, T.; Baiker, A. Oxidation of alcohols with molecular oxygen on solid catalysts. Chem. Rev. 2004, 104, 3037-3058. [CrossRef] [PubMed]

25. Tong, X.; Liu, Z.; Yu, L. A tunable process: Catalytic transformation of renewable furfural with aliphatic alcohols in the presence of molecular oxygen. Chem. Commun. 2015, 51, 3674-3677. [CrossRef] [PubMed]

26. Hashmi, A.S.K.; Lothschütz, C.; Ackermann, M.; Doepp, R.; Anantharaman, S.; Marchetti, B.; Bertagnolli, H.; Rominger, F. Gold Catalysis: In situ EXAFS Study of Homogeneous Oxidative Esterification. Chem. Eur. J. 2010, 16, 7933-8215. [CrossRef] [PubMed] 
27. Taaring, E.; Nielsen, I.S.; Egeblad, K.; Madsen, R.; Christensen, C.H. Chemicals from renewables: Aerobic oxidation of furfural and hydroxymethylfurfural over gold catalysts. ChemSusChem 2008, 1, 75-78. [CrossRef] [PubMed]

28. Casanova, O.; Iborra, S.; Corma, A. Biomass into chemicals: One pot-base free oxidative esterification of 5-hydroxymethyl-2-furfural into 2,5-dimethylfuroate with gold on nanoparticulated ceria. J. Catal. 2009, 265, 109-116. [CrossRef]

29. Kegnæs, S.; Mielby, D.; Mentzel, U.V.; Jensen, T.; Fristrup, P.; Riisager, A. One-pot synthesis of amides by aerobic oxidative coupling of alcohols or aldehydes with amines using supported gold and a base as catalyst. Chem. Commun. 2012, 48, 2427-2429. [CrossRef] [PubMed]

30. Hutchings, G.J. Vapor phase hydrochlorination of acetylene: Correlation of catalytic activity of supported metal chloride catalysts. J. Catal. 1985, 96, 292-295. [CrossRef]

31. Abad, A.; Concepcion, P.; Corma, A.; Garcia, H. A collaborative effect between gold and a support induces the selective oxidation of alcohols. Angew. Chem. Int. Ed. 2005, 44, 4066-4069. [CrossRef] [PubMed]

32. Haruta, M.; Kobayashi, T.; Sano, H.; Yamada, N. Novel gold catalysts for the oxidation of carbon monoxide at a temperature far below $0{ }^{\circ} \mathrm{C}$. Chem. Lett. 1987, 16, 405-408. [CrossRef]

33. Hutchings, G.J.; Brust, M.; Schmidbaur, H. Gold-an introductory perspective. Chem. Soc. Rev. 2008, 37, 1759-1765. [CrossRef] [PubMed]

34. Pinna, F.; Olivo, A.; Trevisan, V.; Menegazzo, F.; Signoretto, M.; Manzoli, M.; Boccuzzi, F. The effects of gold nanosize for the exploitation of furfural by selective oxidation. Catal. Today 2013, 203, 196-201. [CrossRef]

35. Jagadeesh, R.V.; Junge, H.; Pohl, M.-M.; Radnik, J.; Brükner, A.; Beller, M. Selective oxidation of alcohols to esters using heterogeneous $\mathrm{Co}_{3} \mathrm{O}_{4}-\mathrm{N} @ \mathrm{C}$ catalysts under mild conditions. J. Am. Chem. Soc. 2013, 135, 10776-10782. [CrossRef] [PubMed]

36. Deng, J.; Song, H.-J.; Cui, M.S.; Du, Y.-P.; Fu, Y. Aerobic oxidation of hydroxymethylfurfural and furfural by using heterogeneous $\mathrm{Co}_{\mathrm{x}} \mathrm{O}_{\mathrm{y}}-\mathrm{N} @ \mathrm{C}$ catalysts. ChemSusChem 2014, 7, 3334-3340. [CrossRef] [PubMed]

37. Kiran, I.N.C.; Lalwani, K.; Sudalai, A. N-heterocyclic carbene catalysed esterification of aromatic aldehydes with alcohols under aerobic conditions. RSC Adv. 2013, 3, 1695-1698. [CrossRef]

38. Fristrup, P.; Johansen, L.B.; Christensen, C.H. Mechanistic investigation of the gold-catalyzed aerobic oxidation of aldehydes: Added insight from Hammett studies and isotopic labelling experiments. Chem. Commun. 2008, 2750-2752. [CrossRef] [PubMed]

39. Menegazzo, F.; Fantinel, T.; Signoretto, M.; Pinna, F.; Manzoli, M. On the process for furfural and HMF oxidative esterification over $\mathrm{Au} / \mathrm{ZrO}_{2}$. J. Catal. 2014, 319, 61-70. [CrossRef]

40. Morterra, C.; Cerrato, G.; Bolis, V.; Di Ciero, S.; Signoretto, M. On the strength of Lewis- and Brønsted-acid sites at the surface of sulfated zirconia catalysts. J. Chem. Soc. Faraday Trans. 1997, 93, 1179-1184. [CrossRef]

41. Bensitel, M.; Saur, O.; Lavalley, J.-C.; Mabilon, G. Acidity of zirconium oxide and sulfated $\mathrm{ZrO}_{2}$ samples. Mater. Chem. Phys. 1987, 17, 249-258. [CrossRef]

42. Lewis, B.; von Elbe, G. Combustion, Flames and Explosion of Gases; Academic Press: New York, NY, USA, 1961.

43. Tsutsumi, K.; Yoshitake, H. Coupling reaction between $\alpha, \beta$-unsaturated aldehyde and methanol catalyzed by gold-supported on mesostructured cerias. Appl. Catal. A Gen. 2014, 484, 64-73. [CrossRef]

44. Gates, B.C. Supported gold catalysts: New properties offered by nanometer and sub-nanometers structures. Chem. Commun. 2013, 49, 7876-7877. [CrossRef] [PubMed]

45. Strakakis, M.; Garcia, H. Catalysis by supported gold nanoparticles: Beyond aerobic oxidative processes. Chem. Rev. 2012, 112, 4469-4506. [CrossRef] [PubMed]

46. Haruta, M. Relevance of Metal Nanoclusters Size Control in Gold (0) Catalytic Chemistry. In Metal Nanoclusters in Catalysis and Materials Science: The Issue of Size Control; Corain, B.S., Schmid, G., Toshima, N., Eds.; Elsevier: Amsterdam, The Netherlands, 2007; pp. 183-189.

47. Hashmi, A.S.K.; Hutchings, G.J. Gold catalysis. Angew. Chem. Int. Ed. 2006, 45, 7896-7936. [CrossRef] [PubMed]

48. Schmid, G.; Corain, B. Nanoparticulated gold: Syntheses, structures, electronics, and reactivities. Eur. J. Inorg. Chem. 2003, 3081-3098. [CrossRef]

49. Guzman, J.; Carretin, S.; Fierro-Gonzales, J.-C.; Hao, Y.; Gates, B.C.; Corma, A. CO oxidation catalyzed by supported gold: Cooperation between gold and nanocrystalline rare-earth supports forms reactive surface superoxide and peroxide species. Angew. Chem. Int. Ed. 2005, 44, 4778-4781. [CrossRef] [PubMed] 
50. Boccuzzi, F.; Chiorino, A.; Manzoli, M.; Lu, P.; Akita, T.; Ichikawa, S.; Haruta, M. Au/TiO 2 nanosized samples: A catalytic, TEM, and FTIR study of the effect of calcination temperature on the CO oxidation. J. Catal. 2001, 202, 256-267. [CrossRef]

51. Avgouropoulos, G.; Manzoli, M.; Boccuzzi, F.; Tabakova, T.; Papavasiliou, J.; Ioannides, T.; Idakiev, V. Catalytic performance and characterization of $\mathrm{Au} /$ doped-ceria catalysts for the preferential CO oxidation reaction. J. Catal. 2008, 256, 237-247. [CrossRef]

52. Carretin, S.; Guzman, J.; Corma, A. Supported gold catalyzes the homocoupling of phenylboronic acid with high conversion and selectivity. Angew. Chem. Int. Ed. 2005, 44, 2242-2245. [CrossRef] [PubMed]

53. Corma, A.; Serna, P. Chemoselective hydrogenation of nitro compounds with supported gold catalysts. Science 2006, 313, 332-333. [CrossRef] [PubMed]

54. Okumura, M.; Akita, T.; Haruta, M. Hydrogenation of 1,3-butadiene and of crotonaldehyde over highly dispersed Au catalysts. Catal. Today 2002, 74, 265-269. [CrossRef]

55. Della Pina, C.; Falletta, E.; Prati, L.; Rossi, M. Selective oxidation using gold. Chem. Soc. Rev. 2008, 37, 2077-2095. [CrossRef] [PubMed]

56. Hutchings, G.J. Nanocrystalline gold and gold-palladium alloy oxidation catalysts: A personal reflection on the nature of the active sites. Dalton Trans. 2008, 5523-5536. [CrossRef] [PubMed]

57. Abad, A.; Corma, A.; Gracia, H. Catalyst parameters determining activity and selectivity of supported gold nanoparticles for the aerobic oxidation of alcohols: The molecular reaction mechanism. Chem. A Eur. J. 2008, 14, 212-222. [CrossRef] [PubMed]

58. Haruta, M.; Daté, M. Advances in the catalysis of Au nanoparticles. Appl. Catal. A 2001, 222, $427-437$. [CrossRef]

59. Ryabenkova, Y.; Miedziak, P.J.; Dummer, N.F.; Taylor, S.H.; Dimitratos, N.; Willock, D.J.; Bethell, D.; Knight, D.W.; Hutchings, G.J. The selective oxidation of 1,2-propanediol by supported gold-based nanoparticulate catalysts. Top. Catal. 2012, 55, 1283-1288. [CrossRef]

60. Dimitraos, N.; Villa, A.; Prati, L.; Hammond, C.; Chan-Thaw, C.E.; Cookson, J.; Bishop, P.T. Effect of the preparation method of supported Au nanoparticles in the liquid phase oxidation of glycerol. Appl. Catal. A 2016, 514, 267-275. [CrossRef]

61. Rogers, S.M.; Catlow, C.R.A.; Chan-Thaw, C.E.; Gianolio, D.; Gibson, E.K.; Gould, A.L.; Jian, N.; Logsdail, A.J.; Palmer, R.E.; Prati, L.; et al. Tailoring gold nanoparticle characteristics and the impact on aqueous-phase oxidation of glycerol. ACS Catal. 2015, 5, 4377-4384. [CrossRef]

62. Christensen, C.H.; Jørgensen, B.; Rass-Hansen, J.; Egeblad, K.; Madsen, R.; Klitgaard, S.K.; Hansen, S.M.; Hansen, M.R.; Andersen, H.C.; Riisager, A. Formation of acetic acid by aqueous-phase oxidation of ethanol with air in the presence of a heterogeneous gold catalyst. Angew. Chem. Int. Ed. 2006, 45, 4648-4651. [CrossRef] [PubMed]

63. Marsden, C.; Taarning, E.; Hansen, D.; Johansen, L.; Klitgaard, S.K.; Egeblad, K.; Christensen, C.H. Aerobic oxidation of aldehydes under ambient conditions using supported gold nanoparticle catalysts. Green Chem. 2008, 10, 168-170. [CrossRef]

64. Signoretto, M.; Menegazzo, F.; Contessotto, L.; Pinna, F.; Manzoli, M.; Boccuzzi, F. Au/ZrO 2 : An efficient and reusable catalyst for the oxidative esterification of renewable furfural. Appl. Catal. B 2013, 129, 287-293. [CrossRef]

65. Manzoli, M.; Boccuzzi, F.; Trevisan, V.; Menegazzo, F.; Signoretto, M.; Pinna, F. Au/ZrO ${ }_{2}$ catalysts for LT-WGSR: Active role of sulfates during gold deposition. Appl. Catal. B 2010, 96, 28-33. [CrossRef]

66. Schubert, M.M.; Hackenberg, S.; Van Veen, A.C.; Muhler, M.; Plzak, V. CO Oxidation over supported gold catalysts- "Inert" and "Active" support materials and their role for the oxygen supply during reaction. J. Catal. 2001, 197, 113-122. [CrossRef]

67. Sinha, A.K.; Seelan, S.; Tsubota, S.; Haruta, M. Catalysis by gold nanoparticles: Epoxidation of propene. Top. Catal. 2004, 29, 95-102. [CrossRef]

68. Turner, M.; Golovko, V.B.; Vaughan, O.P.H.; Abdulkin, P.; Berenguer-Murcia, A.; Tikhov, M.S.; Johnson, B.F.G.; Lambert, R. Selective oxidation with dioxygen by gold nanoparticle catalysts derived from 55-atom clusters. Nature 2008, 454, 981-984. [CrossRef] [PubMed]

69. Menegazzo, F.; Pinna, F.; Signoretto, M.; Trevisan, V.; Boccuzzi, F.; Chiorino, A.; Manzoli, M. Quantitative determination of sites able to chemisorb $\mathrm{CO}$ on $\mathrm{Au} / \mathrm{ZrO}_{2}$ catalysts. Appl. Catal. A 2009, 356, 31-35. [CrossRef] 
70. Miyamura, H.; Yasukawa, T.; Kobayashi, S. Aerobic oxidative esterification of alcohols catalyzed by polymer-incarcerated gold nanoclusters under ambient conditions. Green Chem. 2010, 12, 776-778. [CrossRef]

71. Valden, M.; Lai, X.; Goodman, D.W. Onset of catalytic activity of gold clusters on titania with the appearance of nonmetallic properties. Science 1998, 281, 1647-1650. [CrossRef] [PubMed]

72. Menegazzo, F.; Pinna, F.; Signoretto, M.; Trevisan, V.; Boccuzzi, F.; Chiorino, A.; Manzoli, M. Highly dispersed gold on zirconia: Characterization and activity in low-temperature water gas shift tests. ChemSusChem 2008, 1, 320-326. [CrossRef] [PubMed]

73. Morterra, C.; Bolis, V.; Fubini, B.; Orio, L.; Williams, T.B. A FTIR and HREM study of some morphological and adsorptive properties of monoclinic $\mathrm{ZrO}_{2}$ microcrystals. Surf. Sci. 1991, 251-252, 540-545. [CrossRef]

74. Menegazzo, F.; Manzoli, M.; Chiorino, A.; Boccuzzi, F.; Tabakova, T.; Signoretto, M.; Pinna, F.; Pernicone, N. Quantitative determination of gold active sites by chemisorption and by infrared measurements of adsorbed CO. J. Catal. 2006, 237, 431-434. [CrossRef]

75. Sample Number 17C. Supplied by World Gold Council. Available online: http://www.gold.org (accessed on 15 March 2016).

76. Martra, G. Lewis acid and base sites at the surface of microcrystalline $\mathrm{TiO}_{2}$ anatase: Relationships between surface morphology and chemical behaviour. Appl. Catal. A 2000, 200, 275-285. [CrossRef]

77. Signoretto, M.; Menegazzo, F.; Pinna, F.; Manzoli, M.; Aina, V.; Cerrato, G.; Boccuzzi, F. Oxidative esterification of renewable furfural on gold based catalysts: Which is the best support? J. Catal. 2014, 309, 241-247.

78. Song, X.; Sayari, A. Sulfated zirconia-based strong solid-acid catalysts: Recent progress. Catal. Rev.-Sci. Eng. 1996, 38, 329-412. [CrossRef]

79. Trovarelli, A. Catalytic properties of ceria and $\mathrm{CeO}_{2}$-containing materials. Catal. Rev.-Sci. Eng. 1996, 38, 439-520. [CrossRef]

80. Trevisan, V.; Signoretto, M.; Pinna, F.; Cruciani, G.; Cerrato, G. Investigation on titania synthesis for photocatalytic NOx abatement. Chem. Today 2012, 30, 25-28.

81. Ishida, T.; Ogihara, Y.; Ohashi, H.; Akita, T.; Honma, T.; Oji, H.; Haruta, M. Base-free direct oxidation of 1-octanol to octanoic acid and its octyl ester over supported gold catalysts. ChemSusChem 2012, 5, 2243-2248. [CrossRef] [PubMed]

82. Wang, T.; Shou, H.; Kou, Y.; Liu, H. Base-free aqueous-phase oxidation of non-activated alcohols with molecular oxygen on soluble Pt nanoparticles. Green Chem. 2009, 11, 562-568. [CrossRef]

83. Su, F.Z.; Liu, Y.M.; Wang, L.-C.; Cao, Y.; He, H.-Y.; Fan, K.-N. Ga-Al mixed-oxide-supported gold nanoparticles with enhanced activity for aerobic alcohol oxidation. Angew. Chem. 2008, 120, 340-343. [CrossRef]

84. Carretin, S.; Conceptión, P.; Corma, A.; Lopez Nieto, J.M.; Puntes, V.F. Nanocrystalline $\mathrm{CeO}_{2}$ Increases the Activity of Au for CO Oxidation by Two Orders of Magnitude. Angew. Chem. Int. Ed. 2004, 43, 2538-2540.

85. Longo, A.; Liotta, L.F.; Pantaleo, G.; Giannici, F.; Venezia, A.M.; Martorana, A. Structure of the metal-support interface and oxidation state of gold nanoparticles supported on ceria. J. Phys. Chem. C. 2012, 116, 2960-2966. [CrossRef]

86. Manzoli, M.; Menegazzo, F.; Signoretto, M.; Cruciani, G.; Pinna, F. Effects of synthetic parameters on the catalytic performance of $\mathrm{Au} / \mathrm{CeO}_{2}$ for furfural oxidative esterification. J. Catal. 2015, 330, 465-473. [CrossRef]

87. Kundakovic, L.; Flytzani-Stephanopoulos, M. Cu- and Ag-modified cerium oxide catalysts for methane oxidation. J. Catal. 1998, 179, 203-221. [CrossRef]

88. Badri, A.; Binet, C.; Lavalley, J.-C. Use of methanol as an IR molecular probe to study the surface of polycrystalline ceria. J. Chem. Soc. Faraday Trans. 1997, 93, 1159-1168. [CrossRef]

89. Binet, C.; Daturi, M. Methanol as an IR probe to study the reduction process in ceria-zirconia mixed compounds. Catal. Today 2001, 70, 155-167. [CrossRef]

90. Binet, C.; Daturi, M.; Lavalley, J.-C. IR study of polycrystalline ceria properties in oxidised and reduced states. Catal. Today 1999, 50, 207-225. [CrossRef]

91. Boccuzzi, F.; Chiorino, A.; Manzoli, M.; Andreeva, D.; Tabakova, T. FTIR study of the low-temperature water gas shift reaction on $\mathrm{Au} / \mathrm{Fe}_{2} \mathrm{O}_{3}$ and $\mathrm{Au} / \mathrm{TiO}_{2}$ catalysts. J. Catal. 1999, 188, 176-185. [CrossRef]

92. Tabakova, T.; Boccuzzi, F.; Manzoli, M.; Andreeva, D. FTIR study of low-temperature water-gas shift reaction on gold/ceria catalyst. Appl. Catal. A 2003, 252, 385-397. [CrossRef] 
93. Manzoli, M.; Boccuzzi, F.; Chiorino, A.; Vindigni, F.; Deng, W.; Flytzani-Stephanopoulos, M. Spectroscopic features and reactivity of $\mathrm{CO}$ adsorbed on different $\mathrm{Au} / \mathrm{CeO}_{2}$ catalysts. J. Catal. 2007, 245, 308-315. [CrossRef]

94. Smolentseva, E.; Costa, V.V.; Cotta, R.F.; Smakova, O.; Beloshapkin, S.; Gusevskaya, E.V.; Simakov, A. Aerobic oxidative esterification of benzyl alcohol and acetaldehyde over gold supported on nanostructured ceria-alumina mixed oxides. Chem CatChem 2015, 7, 1011-1017. [CrossRef]

95. Sie, S.T. Consequences of catalyst deactivation for process design and operation. Appl. Catal. A Gen. 2001, 212, 129-151. [CrossRef]

96. Sadana, A.; Doraiswamy, L.K. Effect of catalyst fouling in fixed-, moving-, and fluid-bed reactors. J. Catal. 1971, 23, 147-157. [CrossRef]

97. Douglas, J.M.; Reiff, E.K., Jr.; Kittrell, J.R. Process design with catalyst deactivation. Chem. Eng. Sci. 1980, 35, 322-329. [CrossRef]

98. Sá, J.; Taylor, S.F.R.; Daly, H.; Goguet, A.; Tiruvalam, R.; He, Q.; Kiely, C.J.; Hutchings, G.H.; Hardacre, C. Redispersion of gold supported on oxides. ACS Catal. 2012, 2, 552-560. [CrossRef]

99. Walsh, M.J.; Yoshida, K.; Pay, M.L.; Gai, P.L.; Boyes, E.D. On the effect of atomic structure on the activity and deactivation of catalytic gold nanoparticles. ChemCatChem 2012, 4, 1638-1644. [CrossRef]

100. Tebandeke, E.; Coman, C.; Guillois, K.; Canning, G.; Ataman, E.; Knudsen, J.; Wallenberg, L.R.; Ssekaalo, H.; Schnadt, J.; Wendt, O.F. Epoxidation of olefins with molecular oxygen as the oxidant using gold catalysts supported on polyoxometalates. Green Chem. 2014, 16, 1586-1593. [CrossRef]

101. Signoretto, M.; Menegazzo, F.; Trevisan, V.; Pinna, F.; Manzoli, M.; Boccuzzi, F. Investigation on the stability of supported gold nanoparticles. Catalysts 2013, 3, 656-670. [CrossRef]

102. Sha, J.; Zheng, E.-J.; Zhou, W.-J.; Liebens, A.; Pera-Titus, M. Selective oxidation of fatty alcohol ethoxylates with $\mathrm{H}_{2} \mathrm{O}_{2}$ over Au catalysts for the synthesis of alkyl ether carboxylic acids in alkaline solution. J. Catal. 2016, 337, 199-207. [CrossRef]

(C) 2016 by the authors; licensee MDPI, Basel, Switzerland. This article is an open access article distributed under the terms and conditions of the Creative Commons Attribution (CC-BY) license (http://creativecommons.org/licenses/by/4.0/). 